\title{
Non-Vitamin K Antagonist Oral Anticoagulants in Medical Conditions at High Risk of Thromboembolism beyond Atrial Fibrillation
}

\author{
Keun-Sik Hong \\ Department of Neurology, Inje University Ilsan Paik Hospital, Inje University College of Medicine, Goyang, Korea
}

Non-Vitamin K antagonist oral anticoagulants (NOACs) have been extensively investigated in medical conditions at high risk of venous or arterial thrombosis other than atrial fibrillation (AF), including hip or knee arthroplasty, acute venous thromboembolism (VTE), cancer-associated VTE, acute coronary syndrome (ACS), stable atherosclerotic vascular disease, chronic heart failure, and embolic stroke of undetermined source (ESUS). Two large ESUS trials failed to show the benefit of rivaroxaban or dabigatran, and large randomized controlled trial (RCT) data of NOACs are lacking for another potential candidates of patent foramen ovale-related stroke, acute ischemic stroke, and cerebral venous thrombosis. On the other hand, high quality evidences of NOACs have been compiled for VTE prophylaxis after hip or knee arthroplasty, acute VTE, cancer-associated VTE, and concomitant ACS and AF, which have been reflected in clinical practice guidelines. In addition, RCTs showed the benefit of very low dose rivaroxaban in combination with antiplatelet therapy in patients with ACS and in those with stable cardiovascular disease. This article summarizes the accumulated evidences of NOACs in cardiovascular diseases beyond AF, and aims to inform healthcare providers of optimal regimens tailored to individual medical conditions and help investigators design future clinical trials.

Keywords Anticoagulants; Stroke; Atrial fibrillation; Acute coronary syndrome; Venous thromboembolism; Cardiovascular diseases

\author{
Correspondence: Keun-Sik Hong \\ Department of Neurology, Stroke Center, \\ Inje University llsan Paik Hospital, Inje \\ University College of Medicine, 170 \\ Juhwa-ro, Ilsanseo-gu, Goyang 10380, \\ Korea \\ Tel: +82-31-910-7680 \\ Fax: +82-31-910-7368 \\ E-mail:nrhks@paik.ac.kr
}

Received: July 30, 2019

Revised: September 2, 2019

Accepted: September 21, 2019

\section{Introduction}

Pivotal randomized controlled trials (RCTs) demonstrated the efficacy and safety of non-vitamin $\mathrm{K}$ antagonist oral anticoagulants (NOACs) for stroke prevention in atrial fibrillation (AF), ${ }_{1}^{1-4}$ and major AF guidelines recommend NOACs over warfarin. ${ }^{5,6}$ Even before the first RCT in AF was published in 2009, large RCTs had already demonstrated the benefit of NOACs for preventing venous thromboembolism (VTE) in patients undergoing hip or knee arthroplasty. ${ }^{7-11}$ These RCT findings and the convenience for clinical use accelerated the investigation of NOACs in diverse medical conditions at high risk of venous or arterial thrombosis. In particular, large RCTs have been completed or are ongoing in acute VTE with or without cancer, acute coronary syndrome (ACS) with or without AF, stable atherosclerotic vascular disease, chronic heart failure (CHF), and embolic stroke of undetermined source (ESUS), and the evidences from pivotal RCTs have been reflected in clinical practice guidelines. The NOAC regimens with proven efficacy in individual medical conditions are variable with regard to dose, duration, and combination with other antithrombotics, and thereby physicians should recognize optimal regimens for specific conditions to 
maximize benefit and minimize risk.

This topical review summarizes the trial findings of NOACs in diverse medical conditions other than AF (Table 1), and aims to inform healthcare providers of the accumulated evidences applicable to clinical practice. Investigators should also acknowledge the lessons from the earlier successful and unsuccessful trials to design future clinical trials.

\section{Embolic stroke of undetermined source}

ESUS, nonlacunar ischemic strokes without well-recognized cardioembolic source or $>50 \%$ proximal arterial stenosis, ${ }_{1}^{12}$ accounts for approximately $20 \%$ of ischemic strokes, and has a high risk of recurrent stroke even with antiplatelet therapy. The proposed stroke mechanisms in ESUS include cardiac embolism associated with minor-risk cardioembolic sources or undetected $A F$, arterial embolism from ulcerative plaques of $<50 \%$ proximal arterial stenosis or aorta, paradoxical embolism, or hypercoagulable status associated with covert cancer or systemic diseases. Based on the favorable benefit-risk profiles observed in pivotal AF trials, it was hypothesized that NOACs compared to antiplatelet therapy would be more effective to prevent recurrent stroke in patients with ESUS. To date, New Approach Rivaroxaban Inhibition of Factor Xa in a Global Trial versus ASA to Prevent Embolism in Embolic Stroke of Undetermined Source (NAVIGATE ESUS) and Randomized, double-blind, Evaluation in secondary Stroke Prevention comparing the EfficaCy and safety of the oral Thrombin inhibitor dabigatran etexilate vs. acetylsalicylic acid in patients with Embolic Stroke of Undetermined Source (RE-SPECT ESUS) have been completed, ${ }^{13,14}$ and AtRial Cardiopathy and Antithrombotic Drugs In prevention After cryptogenic stroke (ARCARDIA) and Apixaban for Treatment of Embolic Stroke of Undetermined Source (ATTICUS) are underway. ${ }^{15,16}$

NAVIGATE ESUS $(n=7,213)$ compared rivaroxaban $(15 \mathrm{mg}$ once daily [OD]) and aspirin (100 mg OD). The median interval from stroke onset to randomization was 37 days. The trial was early terminated because of a higher bleeding risk and little chance of demonstrating a benefit of rivaroxaban over aspirin when 74\% of the anticipated efficacy events had occurred. The median follow-up duration was 11 months. The rivaroxaban and aspirin groups did not differ in the risks of first recurrent stroke or systemic embolism (primary efficacy outcome) (5.1\%/year vs. 4.8\%/ year; hazard ratio [HR], 1.07; 95\% confidence interval [Cl], 0.87 to $1.33 ; P=0.52)$ and recurrent ischemic stroke $(4.7 \% /$ year vs. $4.7 \%$ /year; $\mathrm{HR}, 1.01 ; 95 \% \mathrm{Cl}, 0.81$ to 1.26$)$. However, rivaroxaban vs. aspirin had more major bleedings (1.8\%/year vs. 0.7\%/year; $\mathrm{HR}, 2.72 ; 95 \% \mathrm{Cl}, 1.68$ to $4.39 ; P<0.001)$ and more symptomatic intracranial hemorrhages (0.6\%/year vs. 0.1\%/year; HR, 4.02;
95\% Cl, 1.51 to $10.7 ; P=0.003) .{ }^{13}$

Arterial embolism from carotid plaque or mild carotid stenosis $(<50 \%)$ might be better prevented with anticoagulation than with antiplatelet. Among patients in NAVIGATE-ESUS, 2,905 (40\%) had carotid plaque, and 490 (11\%) had mild carotid stenosis. Rivaroxaban was not superior to aspirin for preventing recurrent ischemic stroke in patients with carotid plaque (5.9\%/year vs. 4.9\%/year; HR, $1.20 ; 95 \% \mathrm{Cl}, 0.86$ to $1.68)$ and in those with mild carotid stenosis (5.0\%/year vs. $5.9 \% /$ year; HR, $0.85 ; 95 \% \mathrm{Cl} 0.39$ to 1.87 ). The risk of major bleeding was higher with rivaroxaban versus aspirin in these subgroups. About two-thirds of carotid plaques were present in the carotid artery ipsilateral to the index stroke and had a strong trend of higher risk of recurrent ischemic stroke, supporting that carotid plaque is an important culprit lesion in ESUS. $^{17}$ Therefore, future ESUS trials for NOACs might need to exclude patients for whom carotid atherosclerosis is likely a source of arterial embolism.

RE-SPECT ESUS ( $n=5,390$ ) compared dabigatran (150 or $110 \mathrm{mg}$ in age $\geq 75$ or creatinine clearance $[\mathrm{CrCl}] 30$ to $50 \mathrm{~mL} / \mathrm{min}$ twice daily [BID]) and aspirin (100 mg OD). The median interval from stroke onset to randomization was 44 days and the median follow-up duration was 19 months. The risk of recurrent stroke (primary efficacy outcome) did not differ between the dabigatran and aspirin groups (4.1\%/year vs. 4.8\%/year; $\mathrm{HR}, 0.85 ; 95 \% \mathrm{Cl}, 0.69$ to $1.03 ; P=0.10)$. Dabigatran versus aspirin was not superior for preventing recurrent ischemic stroke (4.0\%/year vs. 4.7\%/year; HR, $0.84 ; 95 \% \mathrm{Cl}, 0.68$ to 1.03 ) and composite of stroke, myocardial infarction (MI), or vascular death (4.8\%/year vs. 5.4\%/year; HR, $0.88 ; 95 \% \mathrm{Cl}, 0.73$ to 1.06 ). Dabigatran versus aspirin was not associated with more major bleedings (primary safety outcome) (1.7\%/year vs. $1.4 \%$ /year; $\mathrm{HR}, 1.19 ; 95 \% \mathrm{Cl}, 0.85$ to 1.66 ) or intracranial hemorrhages (0.7\%/year vs. 0.7\%/year; $\mathrm{HR}, 0.98 ; 95 \% \mathrm{Cl}$, 0.60 to 1.60 ). However, there were more major or clinically relevant nonmajor (CRNM) bleedings with dabigatran (3.3\%/year vs. 2.3\%/year; HR, 1.44; 95\% Cl, 1.12 to 1.85). Of note, post hoc exploratory analysis suggested that there was no difference in the recurrent stroke risk during the first year, but the difference in favor of dabigatran was significant after 1 year. Increase in the prevalence of cardioembolic sources including undetected AF over time might account for the temporal pattern, but it was not systematically assessed. ${ }^{14}$

Discrepancy in the results between NAVIGATE ESUS and RESPECT ESUS are noted. In NAVIGATE ESUS, rivaroxaban versus aspirin had more major bleeding and intracranial hemorrhage. However, in RE-SPECT ESUS, there was no significant differences between dabigatran and aspirin in the risks of major bleeding and intracranial hemorrhage. On the other hand, the risk of re- 
Table 1. Randomized clinical trials of NOACs in cardiovascular disease beyond AF

\begin{tabular}{|c|c|c|c|c|c|}
\hline Trial & Size & NOAC & Comparator & $\begin{array}{c}\text { Main efficacy outcome rates, } \\
\text { HR or RR }(95 \% \mathrm{Cl})\end{array}$ & $\begin{array}{c}\text { Main safety outcome rates, } \\
\text { HR or RR }(95 \% \mathrm{Cl})\end{array}$ \\
\hline \multicolumn{6}{|l|}{ ESUS } \\
\hline NAVIGATE ESUS & 7,213 & $\begin{array}{l}\text { Rivaroxaban } 15 \mathrm{mg} \\
\text { OD }\end{array}$ & Aspirin 100 mg OD & $\begin{array}{l}\text { Recurrent stroke or systemic } \\
\text { embolism: } 1.07 \text { (0.87-1.33) }\end{array}$ & Major bleeding: 2.72 (1.68-4.39) \\
\hline RE-SPECT ESUS & 5,390 & $\begin{array}{l}\text { Dabigatran } 150 \mathrm{mg} \\
\text { (or 110) BID }\end{array}$ & Aspirin 100 mg OD & Recurrent stroke: 0.84 (0.68-1.03) & Major bleeding: 1.19 (0.85-1.66) \\
\hline ATTICUS & 500 & $\begin{array}{l}\text { Apixaban } 5 \text { mg (or } \\
\text { 2.5) BID }\end{array}$ & Aspirin 100 mg OD & New ischemic lesion on MRI & Major or CRNM bleeding \\
\hline ARCARDIA & 1,100 & $\begin{array}{l}\text { Apixaban } 5 \text { mg (or } \\
\text { 2.5) BID }\end{array}$ & Aspirin $81 \mathrm{mg}$ OD & Recurrent stroke & Major bleeding \\
\hline \multicolumn{6}{|l|}{ CVT } \\
\hline RE-SPECT CVT & 120 & $\begin{array}{l}\text { Dabigatran } 150 \mathrm{mg} \\
\text { BID }\end{array}$ & Warfarin & $\begin{array}{l}\text { VTE } \\
\text { No event }\end{array}$ & $\begin{array}{l}\text { Major bleeding } \\
1 \text { vs. } 2 \text { events }\end{array}$ \\
\hline \multicolumn{6}{|l|}{ Noncardioembolic stroke } \\
\hline DATAS II & 300 & $\begin{array}{l}\text { Dabigatran } 150 \mathrm{mg} \\
\text { (or 110) BID }\end{array}$ & $\begin{array}{l}\text { Aspirin } 300 \mathrm{mg} \\
\text { loading and } 81 \\
\text { mg OD }\end{array}$ & $\begin{array}{l}\text { New ischemic lesion on MRI: } 0.64 \\
(0.29-1.44)\end{array}$ & $\begin{array}{l}\text { Symptomatic hemorrhagic transforma- } \\
\text { tion } \\
\text { No event }\end{array}$ \\
\hline \multicolumn{6}{|l|}{ ACS without AF } \\
\hline RE-DEEM & 1,861 & $\begin{array}{l}\text { Dabigatran 50-150 } \\
\text { mg BID }\end{array}$ & Placebo & $\begin{array}{l}\text { D-dimer level } \\
\text { Significant reduction }\end{array}$ & $\begin{array}{l}\text { Major or CRNM bleedings } \\
\text { Dose-dependent increase }\end{array}$ \\
\hline ATLAS ACS-TIMI 46 & 3,491 & $\begin{array}{l}\text { Rivaroxaban 5-20 mg } \\
\text { OD }\end{array}$ & Placebo & $\begin{array}{l}\text { All-cause death, } \mathrm{MI}, \text { stroke, or } \\
\text { revascularization: } 0.79(0.60-1.05)\end{array}$ & $\begin{array}{l}\text { Major or CRNM bleeding } \\
\text { Dose-dependent increase }\end{array}$ \\
\hline ATLAS ACS 2-TIMI 51 & 15,526 & $\begin{array}{l}\text { Rivaroxaban } 2.5 \text { and } \\
5 \mathrm{mg} \mathrm{BID}\end{array}$ & Placebo & $\begin{array}{l}\text { Vascular death, MI, or stroke } \\
\text { Rivaroxaban } 2.5 \mathrm{mg} \text { BID: } 0.84 \text { (0.72- } \\
\text { 0.97) } \\
\text { Rivaroxaban } 5 \mathrm{mg} \text { BID: } 0.85 \text { (0.73- } \\
\text { 0.98) }\end{array}$ & $\begin{array}{l}\text { Major bleeding not related to CABG } \\
\text { Combined } 3.96(2.46-6.38)\end{array}$ \\
\hline APPRAISE & 1,715 & $\begin{array}{l}\text { Apixaban } 2.5 \mathrm{mg} \mathrm{BID} \\
\text { to } 20 \mathrm{mg} \mathrm{OD}\end{array}$ & Placebo & $\begin{array}{l}\text { Vascular death, MI, severe ischemic, or } \\
\text { ischemic stroke } \\
\text { Trends favoring apixaban } 2.5 \mathrm{mg} \mathrm{BID} \\
\text { and } 10 \mathrm{mg} \mathrm{OD}\end{array}$ & $\begin{array}{l}\text { Major or CRNM bleeding } \\
\text { Dose-dependent increase }\end{array}$ \\
\hline APPRAISE ॥ & 7,392 & $\begin{array}{l}\text { Apixaban } 5 \mathrm{mg} \text { (or } \\
\text { 2.5) BID }\end{array}$ & Placebo & $\begin{array}{l}\text { Vascular death, Ml, or ischemic stroke: } \\
0.95(0.80-1.11)\end{array}$ & Major bleeding: 2.59 (1.50-4.46) \\
\hline GEMINI-ACS-1 & 3,037 & $\begin{array}{l}\text { Rivaroxaban } 2.5 \mathrm{mg} \\
\text { BID }\end{array}$ & Aspirin 100 mg OD & $\begin{array}{l}\text { Vascular death, Ml, stroke, or definite } \\
\text { stent thrombosis }\end{array}$ & Major bleeding not related to CABG \\
\hline \multicolumn{6}{|c|}{ Stable atherosclerotic disease } \\
\hline COMPASS & 27,395 & $\begin{array}{l}\text { Rivaroxaban } 2.5 \mathrm{mg} \\
\text { BID plus aspirin } 100 \\
\text { mg OD and } \\
\text { rivaroxaban } 5 \mathrm{mg} \\
\text { BID }\end{array}$ & Aspirin 100 mg OD & $\begin{array}{l}\text { Vascular death, Ml, or stroke } \\
\text { Rivaroxaban } 2.5 \mathrm{mg} \text { BID plus aspirin } \\
100 \mathrm{mg}: 0.76 \text { (0.66-0.86) } \\
\text { Rivaroxaban } 5 \mathrm{mg} \text { BID: } 0.90 \text { (0.79- } \\
\text { 1.03) }\end{array}$ & $\begin{array}{l}\text { Major bleeding } \\
\text { Rivaroxaban } 2.5 \text { mg BID plus aspirin } \\
100 \text { mg: } 1.70 \text { (1.40-2.05) } \\
\text { Rivaroxaban } 5 \text { mg BID: } 1.51 \text { (1.25- } \\
\text { 1.84) }\end{array}$ \\
\hline \multicolumn{6}{|l|}{ ACS with AF } \\
\hline PIONEER AF-PCI & 2,124 & $\begin{array}{l}\text { Rivaroxaban } 15 \mathrm{mg} \\
\text { OD plus } \mathrm{P}_{2} \mathrm{Y}_{12} \\
\text { inhibitor and rivar- } \\
\text { oxaban } 2.5 \mathrm{mg} \text { BID } \\
\text { plus DAPT }\end{array}$ & Warfarin plus DAPT & $\begin{array}{l}\text { Vascular death, MI, or stroke } \\
\text { Rivaroxaban } 15 \mathrm{mg} \text { OD plus } \mathrm{P} 2 \mathrm{Y}_{12} \\
\text { inhibitor: } 1.08 \text { (0.69-1.68) } \\
\text { Rivaroxaban } 2.5 \mathrm{mg} \text { BID plus DAPT: } \\
0.93(0.59-1.48)\end{array}$ & $\begin{array}{l}\text { Major or CRNM bleeding } \\
\text { Rivaroxaban } 15 \mathrm{mg} \text { OD plus P2Y } 12 \\
\text { inhibitor: } 0.59(0.47-0.76) \\
\text { Rivaroxaban } 2.5 \mathrm{mg} \text { BID plus DAPT: } \\
0.63(0.50-0.80)\end{array}$ \\
\hline RE-DUAL PCI & 2,725 & $\begin{array}{l}\text { Dabigatran } 110 \mathrm{mg} \\
\text { plus } \mathrm{P}_{12} \mathrm{Y}_{12} \text { inhibitor } \\
\text { and Dabigatran } \\
150 \mathrm{mg} \text { BID plus } \\
\text { P2Y }_{12} \text { inhibitor }\end{array}$ & $\begin{array}{l}\text { Warfarin plus } \\
\text { DAPT }\end{array}$ & $\begin{array}{l}\text { Thromboembolic events, death, or } \\
\text { unplanned revascularization } \\
\text { Combined: } 1.04 \text { (0.84-1.29) }\end{array}$ & $\begin{array}{l}\text { Major or CRNM bleeding } \\
\text { Dabigatran } 110 \mathrm{mg} \text { plus } \mathrm{P}_{2} \mathrm{Y}_{12} \text { inhibi- } \\
\text { tor: } 0.52(0.42-0.63) \\
\text { Dabigatran } 150 \mathrm{mg} \text { BID plus P2Y } \\
\text { inhibitor: } 0.72(0.58-0.88)\end{array}$ \\
\hline
\end{tabular}


Table 1. Continued

\begin{tabular}{|c|c|c|c|c|c|}
\hline Trial & Size & NOAC & Comparator & $\begin{array}{c}\text { Main efficacy outcome rates, } \\
\text { HR or RR }(95 \% \mathrm{Cl})\end{array}$ & $\begin{array}{c}\text { Main safety outcome rates, } \\
\text { HR or RR }(95 \% \mathrm{Cl})\end{array}$ \\
\hline AUGUSTUS & 4,614 & $\begin{array}{l}\text { Apixaban } 5 \mathrm{mg} \text { (or } \\
\text { 2.5) BID plus aspirin } \\
\text { or placebo }\end{array}$ & $\begin{array}{l}\text { Warfarin plus aspi- } \\
\text { rin or placebo }\end{array}$ & $\begin{array}{l}\text { Death or hospitalization } \\
\text { Apixaban vs. warfarin: } 0.83(0.74- \\
0.93) \\
\text { Aspirin vs. placebo: } 1.08(0.96-1.21)\end{array}$ & $\begin{array}{l}\text { Major or CRNM bleeding } \\
\text { Apixaban vs. warfarin: } 0.69 \text { (0.58-0.81) } \\
\text { Aspirin vs. placebo: } 1.89(1.59-2.24)\end{array}$ \\
\hline ENTRUST-AF-PCI & 1,500 & $\begin{array}{l}\text { Edoxaban } 60 \mathrm{mg} \text { (or } \\
\text { 30) OD plus } \mathrm{P} \mathrm{Y}_{12} \\
\text { inhibitor }\end{array}$ & Warfarin plus DAPT & $\begin{array}{l}\text { Vascular death, stroke, systemic } \\
\text { embolism, MI, or definite stent } \\
\text { thrombosis. }\end{array}$ & Major or CRNM bleeding \\
\hline \multicolumn{6}{|l|}{ CHF } \\
\hline COMMANDER-HF & 5,022 & $\begin{array}{l}\text { Rivaroxaban } 2.5 \mathrm{mg} \\
\text { BID }\end{array}$ & Placebo & $\begin{array}{l}\text { All-cause death, MI, or stroke: } 0.94 \\
(0.84-1.05)\end{array}$ & $\begin{array}{l}\text { Fatal bleeding or bleeding into a critical } \\
\text { space: } 0.80(0.43-1.49)\end{array}$ \\
\hline \multicolumn{6}{|c|}{ DVT prophylaxis in THA/TKA } \\
\hline RE-NOVATE & 3,494 & $\begin{array}{l}\text { Dabigatran } 150 \text { and } \\
220 \mathrm{mg} \mathrm{OD}\end{array}$ & $\begin{array}{l}\text { Enoxaparin } 40 \mathrm{mg} \\
\text { OD }\end{array}$ & $\begin{array}{l}\text { Total VTE or all-cause death } \\
\text { Noninferiority: } 8.6 \% \text { vs. } 6.0 \% \text { vs. } 6.7 \%\end{array}$ & $\begin{array}{l}\text { Major, CRNM, or minor bleeding } \\
\text { NSD: } 2.0 \% \text { vs. } 1.3 \% \text { vs. } 1.6 \%\end{array}$ \\
\hline RE-NOVATE II & 2,055 & $\begin{array}{l}\text { Dabigatran } 220 \mathrm{mg} \\
\text { OD }\end{array}$ & $\begin{array}{l}\text { Enoxaparin } 40 \mathrm{mg} \\
\text { OD }\end{array}$ & $\begin{array}{l}\text { Total VTE or all-cause death } \\
\text { Noninferiority: } 7.7 \% \text { vs. } 8.8 \%\end{array}$ & $\begin{array}{l}\text { Major bleeding } \\
\text { NSD: } 1.4 \% \text { vs. } 0.9 \%\end{array}$ \\
\hline RE-MODEL & 2,615 & $\begin{array}{l}\text { Dabigatran } 150 \text { and } \\
220 \mathrm{mg} \mathrm{OD}\end{array}$ & $\begin{array}{l}\text { Enoxaparin } 40 \mathrm{mg} \\
\text { OD }\end{array}$ & $\begin{array}{l}\text { Total VTE or all-cause death } \\
\text { Noninferiority: } 40.5 \% \text { vs. } 36.4 \% \text { vs. } \\
37.7 \%\end{array}$ & $\begin{array}{l}\text { Major, CRNM, or minor bleeding } \\
\text { NSD: } 1.3 \% \text { vs. } 1.5 \% \text { vs. } 1.3 \%\end{array}$ \\
\hline RE-MOBILIZE & 2,076 & $\begin{array}{l}\text { Dabigatran } 150 \text { and } \\
220 \mathrm{mg} \mathrm{OD}\end{array}$ & $\begin{array}{l}\text { Enoxaparin } 30 \mathrm{mg} \\
\text { BID }\end{array}$ & $\begin{array}{l}\text { Total VTE or all-cause death } \\
\text { Inferiority: } 33.7 \% \text { vs. } 31.1 \% \text { vs. } 25.3 \%\end{array}$ & $\begin{array}{l}\text { Major or CRNM bleeding } \\
\text { NSD: } 3.3 \% \text { vs. } 3.1 \% \text { vs. } 3.8 \%\end{array}$ \\
\hline RECORD 1 & 4,541 & $\begin{array}{l}\text { Rivaroxaban } 10 \mathrm{mg} \\
\text { OD }\end{array}$ & $\begin{array}{l}\text { Enoxaparin } 40 \mathrm{mg} \\
\text { OD }\end{array}$ & $\begin{array}{l}\text { Total VTE or all-cause death } \\
\text { Superiority: } 1.1 \% \text { vs. } 3.7 \%\end{array}$ & $\begin{array}{l}\text { Major bleeding } \\
\text { NSD: } 0.3 \% \text { vs. } 0.1 \%\end{array}$ \\
\hline RECORD 2 & 2,509 & $\begin{array}{l}\text { Rivaroxaban } 10 \mathrm{mg} \\
\text { OD }\end{array}$ & $\begin{array}{l}\text { Enoxaparin } 40 \mathrm{mg} \\
\text { OD }\end{array}$ & $\begin{array}{l}\text { Total VTE or all-cause death } \\
\text { Superiority: } 2.0 \% \text { vs. } 9.3 \%\end{array}$ & $\begin{array}{l}\text { Major bleeding } \\
\text { NSD: } 1 \text { vs. } 1 \text { events }\end{array}$ \\
\hline RECORD 3 & 2,531 & $\begin{array}{l}\text { Rivaroxaban } 10 \mathrm{mg} \\
\text { OD }\end{array}$ & $\begin{array}{l}\text { Enoxaparin } 40 \mathrm{mg} \\
\text { OD }\end{array}$ & $\begin{array}{l}\text { Total VTE or all-cause death } \\
\text { Superiority: } 9.6 \% \text { vs. } 18.9 \%\end{array}$ & $\begin{array}{l}\text { Major bleeding } \\
\text { NSD: } 0.6 \% \text { vs. } 0.5 \%\end{array}$ \\
\hline RECORD 4 & 3,148 & $\begin{array}{l}\text { Rivaroxaban } 10 \mathrm{mg} \\
\text { OD }\end{array}$ & $\begin{array}{l}\text { Enoxaparin } 30 \mathrm{mg} \\
\text { BID }\end{array}$ & $\begin{array}{l}\text { Total VTE or all-cause death } \\
\text { Superiority: } 6.9 \% \text { vs. } 10.1 \%\end{array}$ & $\begin{array}{l}\text { Major bleeding } \\
\text { NSD: } 0.7 \% \text { vs. } 0.3 \%\end{array}$ \\
\hline ADVANCE 1 & 3,195 & Apixaban 2.5 mg BID & $\begin{array}{l}\text { Enoxaparin } 30 \mathrm{mg} \\
\text { BID }\end{array}$ & $\begin{array}{l}\text { Total VTE or all-cause death } \\
\text { Similar, but not noninferior: } 9.0 \% \text { vs. } \\
8.8 \%\end{array}$ & $\begin{array}{l}\text { Major or CRNM bleeding } \\
\text { Significant reduction: } 2.9 \% \text { vs. } 4.3 \%\end{array}$ \\
\hline ADVANCE 2 & 3,057 & Apixaban 2.5 mg BID & $\begin{array}{l}\text { Enoxaparin } 40 \mathrm{mg} \\
\text { OD }\end{array}$ & $\begin{array}{l}\text { Total VTE or all-cause death: } 0.62 \\
(0.51-0.74)\end{array}$ & $\begin{array}{l}\text { Major or CRNM bleeding } \\
\text { NSD: } 4 \% \text { vs. } 5 \%\end{array}$ \\
\hline ADVANCE 3 & 3,866 & Apixaban 2.5 mg BID & $\begin{array}{l}\text { Enoxaparin } 40 \mathrm{mg} \\
\text { OD }\end{array}$ & $\begin{array}{l}\text { Total VTE or all-cause death: } 0.36 \\
(0.22-0.54)\end{array}$ & $\begin{array}{l}\text { Major or CRNM bleeding } \\
\text { NSD: } 4.8 \% \text { vs. } 5.0 \%\end{array}$ \\
\hline STARS E-3 & 716 & Edoxaban $30 \mathrm{mg}$ OD & $\begin{array}{l}\text { Enoxaparin } 20 \mathrm{mg} \\
\text { BID }\end{array}$ & $\begin{array}{l}\text { Symptomatic PE or asymptomatic and } \\
\text { symptomatic DVT } \\
\text { Superiority: } 7.4 \% \text { vs. } 13.9 \%\end{array}$ & $\begin{array}{l}\text { Major or CRNM bleeding } \\
\text { NSD: } 6.2 \% \text { vs. } 3.7 \%\end{array}$ \\
\hline STARS J-V & 610 & Edoxaban $30 \mathrm{mg}$ OD & $\begin{array}{l}\text { Enoxaparin } 20 \mathrm{mg} \\
\text { BID }\end{array}$ & $\begin{array}{l}\text { Symptomatic PE or asymptomatic and } \\
\text { symptomatic DVT } \\
\text { Superiority: } 2.4 \% \text { vs. } 6.9 \%\end{array}$ & $\begin{array}{l}\text { Major or CRNM bleeding } \\
\text { NSD: } 2.6 \% \text { vs. } 3.7 \%\end{array}$ \\
\hline
\end{tabular}

Acute VTE

\begin{tabular}{|c|c|c|c|c|c|}
\hline RE-COVER & 2,564 & $\begin{array}{l}\text { Dabigatran } 150 \mathrm{mg} \\
\text { BID }\end{array}$ & Warfarin & $\begin{array}{l}\text { Recurrent symptomatic VTE or } \\
\text { VTE-related death } \\
\text { Noninferiority: } 2.4 \% \text { vs. } 2.1 \%\end{array}$ & Major bleeding: 0.82 (0.45-1.48) \\
\hline RE-COVER II & 2,589 & $\begin{array}{l}\text { Dabigatran } 150 \mathrm{mg} \\
\text { BID }\end{array}$ & Warfarin & $\begin{array}{l}\text { Recurrent symptomatic VTE or } \\
\text { VTE-related death } \\
\text { Noninferiority: } 1.08(0.64-1.80)\end{array}$ & Major bleeding: 0.69 (0.36-1.32) \\
\hline RE-SONATE & 1,353 & $\begin{array}{l}\text { Dabigatran } 150 \mathrm{mg} \\
\text { BID }\end{array}$ & Placebo & $\begin{array}{l}\text { Recurrent symptomatic VTE or } \\
\text { VTE-related death: } 0.08(0.02-0.25)\end{array}$ & $\begin{array}{l}\text { Major or CRNM bleeding: } 2.92 \text { (1.52- } \\
5.60)\end{array}$ \\
\hline RE-MEDY & 2,866 & $\begin{array}{l}\text { Dabigatran } 150 \mathrm{mg} \\
\text { BID }\end{array}$ & Warfarin & $\begin{array}{l}\text { Recurrent symptomatic VTE or } \\
\text { VTE-related death } \\
\text { Noninferiority: } 1.44(0.78-2.64)\end{array}$ & $\begin{array}{l}\text { Major or CRNM bleeding: } 0.52 \text { (0.41- } \\
\text { 0.71) }\end{array}$ \\
\hline
\end{tabular}


Table 1. Continued

\begin{tabular}{|c|c|c|c|c|c|}
\hline Trial & Size & NOAC & Comparator & $\begin{array}{c}\text { Main efficacy outcome rates, } \\
\text { HR or RR }(95 \% \mathrm{Cl})\end{array}$ & $\begin{array}{l}\text { Main safety outcome rates, } \\
\text { HR or RR }(95 \% \mathrm{Cl})\end{array}$ \\
\hline EINSTEIN-DVT & 3,449 & $\begin{array}{l}\text { Rivaroxaban } 15 \mathrm{mg} \\
\text { BID for } 3 \text { wk and } \\
\text { then } 20 \mathrm{mg} \text { OD } \\
\text { without enoxaparin } \\
\text { bridging }\end{array}$ & $\begin{array}{l}\text { Enoxaparin, } 1.0 \\
\mathrm{mg} / \mathrm{kg} \text { BID } \\
\text { switched to war- } \\
\text { farin or aceno- } \\
\text { coumarol }\end{array}$ & $\begin{array}{l}\text { Recurrent symptomatic VTE or } \\
\text { VTE-related death } \\
\text { Noninferiority: } 0.68 \text { (0.44-1.04) }\end{array}$ & $\begin{array}{l}\text { Major or CRNM bleeding: } 0.97 \text { (0.76- } \\
1.22)\end{array}$ \\
\hline EINSTEIN-PE & 4,832 & $\begin{array}{l}\text { Rivaroxaban } 15 \mathrm{mg} \\
\text { BID for } 3 \text { wk and } \\
\text { then } 20 \mathrm{mg} \text { OD } \\
\text { without enoxaparin } \\
\text { bridging }\end{array}$ & $\begin{array}{l}\text { Enoxaparin, } 1.0 \\
\text { mg/kg BID } \\
\text { switched to war- } \\
\text { farin or aceno- } \\
\text { coumarol }\end{array}$ & $\begin{array}{l}\text { Recurrent symptomatic VTE or } \\
\text { VTE-related death } \\
\text { Noninferiority: } 1.12(0.75-1.68)\end{array}$ & $\begin{array}{l}\text { Major or CRNM bleeding: } 0.90 \text { (0.76- } \\
1.07 \text { ) }\end{array}$ \\
\hline EINSTEIN-extension & 1,197 & $\begin{array}{l}\text { Rivaroxaban } 20 \mathrm{mg} \\
\text { OD }\end{array}$ & Placebo & $\begin{array}{l}\text { Recurrent symptomatic VTE or } \\
\text { VTE-related death: } 0.18 \text { (0.09-0.39) }\end{array}$ & Major bleeding: 4 vs. 0 events \\
\hline AMPLIFY & 5,244 & $\begin{array}{l}\text { Apixaban } 10 \mathrm{mg} \text { BID } \\
\text { for } 7 \text { days and then } \\
5 \mathrm{mg} \text { BID without } \\
\text { enoxaparin bridging }\end{array}$ & $\begin{array}{l}\text { Enoxaparin, } 1.0 \\
\mathrm{mg} / \mathrm{kg} \text { BID } \\
\text { switched to war- } \\
\text { farin }\end{array}$ & $\begin{array}{l}\text { Recurrent symptomatic VTE or } \\
\text { VTE-related death } \\
\text { Noninferiority: } 0.84(0.60-1.18)\end{array}$ & Major bleeding: 0.31 (0.17-0.55) \\
\hline AMPLIFY-EXT & 2,486 & $\begin{array}{l}\text { Apixaban } 2.5 \text { and } 5 \\
\text { mg BID }\end{array}$ & Placebo & $\begin{array}{l}\text { Recurrent symptomatic VTE or } \\
\text { all-cause death } \\
\text { Apixaban } 5 \mathrm{mg} \text { BID: } 0.36(0.25-0.53) \\
\text { Apixaban } 2.5 \mathrm{mg} \mathrm{BID}: 0.33(0.22-0.48)\end{array}$ & $\begin{array}{l}\text { Major bleeding } \\
\text { Apixaban } 5 \text { mg BID: } 1.62(0.96-2.73) \\
\text { Apixaban } 2.5 \text { mg BID: } 1.20(0.69-2.10)\end{array}$ \\
\hline Hokusai-VTE & 8,292 & $\begin{array}{l}\text { Edoxaban } 60 \mathrm{mg} \text { (or } \\
\text { 30) OD }\end{array}$ & Warfarin & $\begin{array}{l}\text { Recurrent symptomatic VTE or } \\
\text { VTE-related death } \\
\text { Noninferiority: } 0.89(0.70-1.13)\end{array}$ & $\begin{array}{l}\text { Major or CRNM bleeding: } 0.81 \text { (0.71- } \\
\text { 0.94) }\end{array}$ \\
\hline \multicolumn{6}{|c|}{ Active cancer and acute VTE } \\
\hline Hokusai-VTE cancer & 1,050 & $\begin{array}{l}\text { Edoxaban } 60 \mathrm{mg} \text { (or } \\
\text { 30) OD }\end{array}$ & $\begin{array}{l}\text { Dalteparin } 200 \\
\text { IU/kg OD for } 1 \mathrm{mo} \\
\text { and then } 150 \mathrm{IU} / \\
\mathrm{kg} \text { kilogram OD }\end{array}$ & $\begin{array}{l}\text { Recurrent VTE or major bleeding. } \\
\text { Noninferiority: } 0.97(0.70-1.36)\end{array}$ & Major bleeding: 1.77 (1.03-3.04) \\
\hline SELECT-D & 406 & $\begin{array}{l}\text { Rivaroxaban } 15 \mathrm{mg} \\
\text { BID for } 3 \text { wk and } \\
\text { then } 20 \mathrm{mg} \mathrm{OD}\end{array}$ & $\begin{array}{l}\text { Dalteparin } 200 \\
\text { IU/kg OD for } 1 \mathrm{mo} \\
\text { and then } 150 \mathrm{IU} / \\
\text { kg kilogram OD }\end{array}$ & Recurrent VTE: 0.43 (0.19-0.99) & Major bleeding: 1.83 (0.68-4.96) \\
\hline ADAM VTE & 300 & $\begin{array}{l}\text { Apixaban } 10 \mathrm{mg} \text { BID } \\
\text { for } 7 \text { days and then } \\
5 \mathrm{mg} \text { BID }\end{array}$ & $\begin{array}{l}\text { Dalteparin } 200 \\
\text { IU/kg OD for } 1 \text { mo } \\
\text { and then } 150 \text { IU/ } \\
\text { kg kilogram OD }\end{array}$ & Recurrent VTE: 0.26 (0.09-0.80) & Major bleeding: 0 vs. 3 events \\
\hline
\end{tabular}

Acute medical illness
APEX
7,513 Betrixaban loading Placebo 160 and $80 \mathrm{mg}$ OD for 35-42 days
Asymptomatic proximal DVT, symp- tomatic VTE, or VTE-related death: $0.76(0.63-0.92)$
Major bleeding: $1.19(0.67-2.12)$
Antiphospholipid Ab syndrome
TRASP
120 Rivaroxaban $20 \mathrm{mg}$ Warfarin (or 15) OD
Thromboembolism, major bleeding, or Major bleeding: 4 vs. 2 events vascular death: 6.7 (1.5-30.5)

NOAC, non-vitamin $\mathrm{K}$ antagonist oral anticoagulant; $\mathrm{AF}$, atrial fibrillation; $\mathrm{HR}$, hazard ratio; $\mathrm{RR}$, relative risk; $\mathrm{Cl}$, confidence interval; ESUS, Embolic Stroke of Undetermined Source; NAVIGATE ESUS, New Approach Rivaroxaban Inhibition of Factor Xa in a Global Trial versus ASA to Prevent Embolism in Embolic Stroke of Undetermined Source; OD, once daily; RE-SPECT ESUS, Randomized, double-blind, Evaluation in secondary Stroke Prevention comparing the EfficaCy and safety of the oral Thrombin inhibitor dabigatran etexilate vs. acetylsalicylic acid in patients with Embolic Stroke of Undetermined Source; BID, twice daily; ATTICUS, Apixaban for Treatment of Embolic Stroke of Undetermined Source; MRI, magnetic resonance imaging; CRNM, clinically relevant nonmajor; ARCARDIA, AtRial Cardiopathy and Antithrombotic Drugs In prevention After cryptogenic stroke; CVT, cerebral venous thrombosis; RE-SPECT CVT, Randomized, Open-label, Exploratory Trial with Blinded Endpoint Adjudication, Comparing Efficacy and Safety of Oral Dabigatran Etexilate Versus Oral Warfarin in Patients With Cerebral Venous and Dural Sinus Thrombosis; VTE, venous thromboembolism; DATAS II, Dabigatran Following Transient Ischemic Attack and Minor Stroke; ACS, acute coronary syndrome; RE-DEEM, RandomizEd Dabigatran Etexilate Dose Finding Study in Patients With Acute Coronary Syndromes Post Index Event With Additional Risk Factors for Cardiovascular Complications Also Receiving Aspirin and Clopidogrel: Multi-centre, Prospective, Placebo Controlled, Cohort Dose Escalation Study; ATLAS ACS-TIMI, Anti-Xa Therapy to Lower Cardiovascular Events in Addition to Standard Therapy in Subjects with Acute Coronary Syndrome-Thrombolysis in Myocardial Infarction; MI, myocardial infarction; CABG, coronary artery bypass grafting; APPRAISE, Apixaban added to DAPT was evaluated in the Apixaban for Prevention of Acute Ischemic Events; GEMINI-ACS-1, Randomized, Double-Blind, Double-Dummy, Active-controlled, Parallel- 
Table 1. Continued

group, Multicenter Study to Compare the Safety of Rivaroxaban Versus Acetylsalicylic Acid in Addition to Either Clopidogrel or Ticagrelor Therapy in Subjects With Acute Coronary Syndrome; COMPASS, Cardiovascular Outcomes for People Using Anticoagulation Strategies; PIONEER AF-PCl, Open-Label, Randomized, Controlled, Multicenter Study Exploring Two Treatment Strategies of Rivaroxaban, and a Dose-Adjusted Oral Vitamin K Antagonist Treatment Strategy in Subjects with Atrial Fibrillation who Undergo Percutaneous Coronary Intervention; DAPT, dual antiplatelet therapy; RE-DUAL PCI, Randomized Evaluation of Dual Antithrombotic Therapy With Dabigatran vs. Triple Therapy With Warfarin in Patients With Nonvalvular Atrial Fibrillation Undergoing Percutaneous Coronary Intervention; AUGUSTUS, An Open-label, 2×2 Factorial, Randomized Controlled, Clinical Trial to Evaluate the Safety of Apixaban vs. Vitamin K Antagonist and Aspirin vs. Aspirin Placebo in Patients With Atrial Fibrillation and Acute Coronary Syndrome or Percutaneous Coronary Intervention; ENTRUST-AF-PCl, Edoxaban Treatment vs. Vitamin K Antagonist in Patients With Atrial Fibrillation Undergoing Percutaneous Coronary Intervention; CHF, chronic heart failure; COMMANDER-HF, Study to Assess the Effectiveness and Safety of Rivaroxaban in Reducing the Risk of Death, Myocardial Infarction, or Stroke in Participants with Heart Failure and Coronary Artery Disease Following an Episode of Decompensated Heart Failure; DVT, deep vein thrombosis; THA, total hip arthroplasty; TKA, total knee arthroplasty; RE-NOVATE, Phase III Randomised, Parallel Group, Double-blind, Active Controlled Study to Investigate the Efficacy and Safety of Orally Administered 220 mg Dabigatran Etexilate Capsules (110 mg Administered on the Day of Surgery Followed by 220 mg Once Daily) Compared to Subcutaneous 40 mg Enoxaparin Once Daily for 28-35 Days, in Prevention of Venous Thromboembolism in Patients With Primary Elective Total Hip Arthroplasty Surgery; NSD, no statistical difference; RE-MODEL, Two Different Dose Regimens of Orally Administered Dabigatran Etexilate Capsules (150 or $220 \mathrm{mg}$ Once Daily Starting With a Half Dose [i.e., 75 or 110 mg] on the Day of Surgery) Compared to Subcutaneous Enoxaparin 40 mg Once Daily for 6-10 Days; RE-M0BILIZE, Phase III, Randomized, Parallel-group, Double-blind, Active Controlled Study to Investigate the Efficacy and Safety of Two Different Dose Regimens (75 mg Day 1 Followed by $150 \mathrm{mg}$ Day 2-completion, and $110 \mathrm{mg}$ Day 1 Followed by $220 \mathrm{mg}$ Day 2-completion) of Dabigatran Etexilate Administered Orally (Capsules), Compared to Enoxaparin $30 \mathrm{mg}$ Twice a Day Subcutaneous for 12-15 Days in Prevention of Venous Thromboembolism in Patients With Primary Elective Total Knee Replacement Surgery; RECORD, REgulation of Coagulation in ORthopedic Surgery to Prevent DVT and PE, Controlled, Double-blind, Randomized Study of BAY 59-7939 in the Extended Prevention of VTE in Patients Undergoing Elective Total Hip Replacement; ADVANCE, Apixaban Dose Orally vs. Anticoagulation with Enoxaparin; STARS, Studying Thrombosis After Replacement Surgery; PE, pulmonary embolism; RE-COVER, Phase III, Randomised, Double Blind, Parallel-group Study of the Efficacy and Safety of Oral Dabigatran Etexilate $150 \mathrm{mg}$ Twice Daily Compared to Warfarin (INR 2.0-3.0) for 6 Month Treatment of Acute Symptomatic Venous Thromboembolism (VTE), Following Initial Treatment (5-10 Days) With a Parenteral Anticoagulant Approved for This Indication; RE-SONATE, Twice-daily Oral Direct Thrombin Inhibitor Dabigatran Etexilate in the Long-term Prevention of Recurrent Symptomatic Proximal Venous Thromboembolism in Patients With Symptomatic Deep-vein Thrombosis or Pulmonary Embolism; RE-MEDY, Twice-daily Oral Direct Thrombin Inhibitor Dabigatran Etexilate in the Long Term Prevention of Recurrent Symptomatic VTE; EINSTEIN, Oral Direct Factor Xa Inhibitor Rivaroxaban in Patients With Acute Symptomatic Deep-Vein Thrombosis or Pulmonary Embolism; AMPLIFY, Apixaban for the Initial Management of Pulmonary Embolism and Deep-Vein Thrombosis as First-Line Therapy; Hokusai-VTE, Phase 3, Randomized, Parallel-Group, Multi-Center, Multi-National Study for the Evaluation of Efficacy and Safety of (LMW) Heparin/Edoxaban Versus (LMW) Heparin/Warfarin in Subjects With Symptomatic Deep-Vein Thrombosis (DVT) and or Pulmonary Embolism (PE); SELECT-D, anticoagulation therapy in SELECTeD cancer patients at risk of recurrence of venous thromboembolism; ADAM VTE, Apixaban and dalteparin in active malignancy associated venous thromboembolism; APEX, Acute Medically III VTE (Venous Thromboembolism) Prevention with Extended Duration Betrixaban; TRASP, Trial on Rivaroxaban in AntiPhospholipid Syndrome.

current ischemic stroke was almost identical between rivaroxaban and aspirin in NAVIGATE ESUS, but was nonsignificantly lower with dabigatran than with aspirin in RE-SPECT ESUS. The observation suggests that dabigatran might be better than rivaroxaban, but indirect comparison limits valid interpretation.

The two ESUS trials showed that neither rivaroxaban nor dabigatran was more effective than aspirin in patients selected with the current ESUS criteria. The heterogeneity of stroke mechanisms in ESUS likely accounts for the neutral results. Covert AF, which benefits most from NOACs, appears less presented in the two trials. During the follow-up, AF was newly detected in only $2 \%$ of the NAVIGATE ESUS population and $0.8 \%$ in the RE-SPECT ESUS population. Therefore, for future trials, the current broad ESUS concept should be modified to reliably identify patients who likely benefit from NOACs.

ARCARDIA and ATIICUS are ongoing to compare apixaban and aspirin in more selective patients who have a high risk of cardiac embolism. ${ }^{15,16}$ ARCADIA is enrolling patients with ESUS and atrial cardiopathy ( $P$-wave terminal force $>5,000 \mu \mathrm{V} \times \mathrm{ms}$ on electrocardiogram, serum $\mathrm{N}$-terminal prohormone of brain natriuretic peptide $>250 \mathrm{pg} / \mathrm{mL}$, or left atrial diameter index $\geq$ $3 \mathrm{~cm} / \mathrm{m}^{2}$ on echocardiogram). The primary endpoint is recur- rent stroke during at least 18-month follow-up, and the estimated sample size is $1,100 .{ }^{15}$ ATTICUS ( $n=500$ planned) is enrolling patients with acute stroke ( $<7$ days from onset), implanted insertable cardiac monitor, and potential risks of cardioembolism (left atrium size $>45 \mathrm{~mm}$, spontaneous echogenic contrast in left atrial appendage, flow velocity in left atrial appendage $\leq 0.2 \mathrm{~m} / \mathrm{sec}$, atrial high rate episodes, patent foramen ovale [PFO], or $\mathrm{CHA}_{2} \mathrm{DS}_{2}-\mathrm{VASc}$ score $\geq 4$ ) to assess new ischemic lesions on follow-up MRI at 12 months. ${ }^{16}$

\section{Patent foramen ovale}

No RCT has specifically assessed NOACs in PFO. In CLOSE (Patent Foramen Ovale Closure or Anticoagulants versus Antiplatelet Therapy to Prevent Stroke Recurrence), oral anticoagulation versus antiplatelet had a trend toward superiority for preventing recurrent stroke ( $\mathrm{HR}, 0.43 ; 95 \% \mathrm{Cl}, 0.1$ to $1.5 ; P=0.17)$. However, only 13 among 187 patients (7.0\%) in the anticoagulation group received NOACs, which did not allow adequate analysis. ${ }^{18}$ Patients with PFO were included in NAVIGATE ESUS and RESPECT ESUS. In NAVIGATE ESUS, 534 patients (7.4\%; 259 randomized to rivaroxaban and 275 to aspirin) had PFO. ${ }^{13}$ In this 
PFO subgroup, the risk of recurrent ischemic stroke was lower with rivaroxaban than with aspirin, but was not statistically different ( $H R, 0.54 ; 95 \% \mathrm{Cl}, 0.22$ to 1.36$])$. In addition, the treatment effect was not modified by the presence of PFO ( $P$ for interaction=0.18).$^{19}$ In RE-SPECT ESUS, 680 patients (12.6\%; 319 in the dabigatran group and 361 in the aspirin group) had PFO. The risk of recurrent stroke was comparable between patients on dabigatran and those on aspirin (5.0\%/year vs. 5.3\%/year; HR, $0.88 ; 95 \% \mathrm{Cl}, 0.45$ to 1.71 ), and the treatment effect was consistent between patients with PFO and those without PFO. ${ }^{14}$

Therefore, the current available evidence does not support NOACs over aspirin in patients with ESUS and PFO. A metaanalysis combining data from NAVIGATE ESUS, PFO in Cryptogenic Stroke Study (PICSS), and CLOSE suggests that anticoagulation (warfarin and NOACs combined) versus aspirin in patients with cryptogenic stroke and PFO might be better for preventing recurrent ischemic stroke (odds ratio, $0.48 ; 95 \% \mathrm{Cl}$, 0.24 to $0.96 ; P=0.04)$ without heterogeneity across the trials $\left(I^{2}=0 \%\right) .{ }^{19}$ Future trials are needed to determine the role of NOACs in cryptogenic stroke and PFO; NOACs versus aspirin in low risk PFO and NOACs versus PFO closure in high risk PFO.

\section{Cerebral venous thrombosis}

The standard therapy in patients with cerebral venous thrombosis (CVT) is parenteral anticoagulation in acute phase and then warfarin for 3 to 12 months or lifelong according to underlying conditions..$^{20}$ NOACs are promising options for long-term oral anticoagulation, but only data from small sized observational studies are available. ${ }^{21-24}$ The 2017 European Stroke Organization guidelines do not recommend NOACs for the treatment of $C V T$, especially during the acute phase because of the very low quality of evidence. ${ }^{25}$ Recently, the results of RE-SPECT CVT $(n=120)$, an exploratory phase III trial to compare dabigatran and warfarin (parenteral heparin for 5 to 15 days in both treatments), ${ }_{1}^{26}$ were presented at the 2018 World Stroke Congress. There were neither thrombotic event nor death in the two groups for up to 24 weeks. Major bleeding events occurred in one patient with dabigatran and two with warfarin. More data from large RCTs are needed to change clinical practice.

\section{Noncardioembolic stroke}

Large phase III trials have evaluated NOACs in non-AF patients with ACS or with stable atherosclerotic vascular disease, but there has been no large RCT in noncardioembolic ischemic stroke. In a small single arm trial $(n=53)$, dabigatran initiated within 24 hours from stroke onset and continued for 30 days was safe without symptomatic hemorrhagic transformation in patients with minor stroke (National Institutes of Health Stroke Scale [NIHSS] score $\leq 3){ }^{27}$

Dabigatran Following Transient Ischemic Attack and Minor Stroke (DATAS) II $(n=300)$, a phase II trial, compared dabigatran (150 or $110 \mathrm{mg}$ for age $>80$ or glomerular filtration rate 30 to $50 \mathrm{~mL} / \mathrm{min} \mathrm{BID}$ ) and aspirin (325 mg loading and $81 \mathrm{mg}$ OD) for 30 days in patients with noncardioembolic transient ischemic attack or acute minor ischemic stroke (NIHSS score $\leq 9$ and lesion volume on diffusion-weighted imaging $<25 \mathrm{~mL}$ ) within 72 hours of symptom onset. ${ }^{28}$ The results presented at the 2018 European Stroke Organization Conference showed that there were no symptomatic hemorrhagic transformation (primary outcome) in both the groups. On follow-up MRI, dabigatran versus aspirin nonsignificantly had more asymptomatic hemorrhagic transformations (7.8\% vs. $3.5 \%$; relative risk [RR], 2.2; $95 \% \mathrm{Cl}, 0.79$ to 6.21$)$ and less recurrent ischemic lesions (6.3\% vs. $9.9 \% ; \mathrm{RR}, 0.64 ; 95 \% \mathrm{Cl}, 0.29$ to 1.44 ).

\section{Acute coronary syndrome without atrial fibrillation}

In ACS, activations of platelet and coagulation pathways are main mechanisms of thrombogenesis, and thereby combination therapy with anticoagulation and antiplatelet is more effective to prevent ischemic events than antiplatelet alone. The current guidelines recommend parenteral anticoagulation in addition to dual antiplatelet therapy (DAPT) during acute hospitalization or percutaneous coronary intervention (PCI). 29,30 After the acute period, DAPT is the current standard of care, but the residual risk of major ischemic vascular events remains high up to 1 year. Studies showed that the formation of thrombin, a key factor in platelet activation and coagulation, remained increased after the acute period, which was associated with an increased risk of cardiac events. ${ }^{31-33}$ In this context, NOACs on top of DAPT have been investigated in ACS without AF.

In RandomizEd Dabigatran Etexilate Dose Finding Study in Patients With Acute Coronary Syndromes Post Index Event With Additional Risk Factors for Cardiovascular Complications Also Receiving Aspirin and Clopidogrel: Multi-centre, Prospective, Placebo Controlled, Cohort Dose Escalation Study (REDEEM; $n=1,861)$, a phase II dose-finding trial, dabigatran (50 to $150 \mathrm{mg} \mathrm{BID)}$ compared to placebo increased the risk of major or CRNM bleeding in a dose-dependent manner. D-dimer levels measured as an efficacy indicator were reduced with all doses of dabigatran, but the reduction was not translated into clinical benefit. ${ }^{34}$

In a phase II dose-selection trial (Anti-Xa Therapy to Lower 
Cardiovascular Events in Addition to Standard Therapy in Subjects with Acute Coronary Syndrome-Thrombolysis in Myocardial Infarction [ATLAS ACS-TIMI 46], $n=3,491$ ), rivaroxaban (at doses 5 to $20 \mathrm{mg}$ OD) compared to placebo increased the risk of clinically significant bleeding in a dose-dependent manner, but reduced composite of death, $\mathrm{MI}$, or stroke. ${ }^{35}$ Based on these findings, ATLAS ACS 2-TIMI 51, a phase III trial $(n=15,526)$, compared rivaroxaban 2.5 and $5 \mathrm{mg}$ BID versus placebo. Composite of vascular death, $\mathrm{Ml}$, or stroke (primary efficacy outcome) was reduced with both the $2.5 \mathrm{mg}$ dose BID (9.1\% vs. $10.7 \% ; \mathrm{HR}, 0.84 ; 95 \% \mathrm{Cl}, 0.72$ to $0.97 ; P=0.02)$ and the $5 \mathrm{mg}$ dose BID ( $8.8 \%$ vs. $10.7 \%$; HR, $0.85 ; 95 \% \mathrm{Cl}, 0.73$ to 0.98 ; $P=0.03)$ compared to placebo. Benefit on vascular death was seen with the $2.5 \mathrm{mg}$ dose BID versus placebo (2.7\% vs. $4.1 \%$; $H R, 0.66 ; 95 \% \mathrm{Cl}, 0.51$ to $0.86 ; P=0.002$ ), but not with the 5 $\mathrm{mg}$ BID dose. However, rivaroxaban versus placebo significantly increased the risk of major bleeding not associated with coronary artery bypass grafting (CABG) $(2.1 \%$ [both rivaroxaban doses combined] vs. $0.6 \% ; \mathrm{HR}, 3.96 ; 95 \% \mathrm{Cl}, 2.46$ to 6.38 ; $P<0.001)$, and the higher dose regimen had a higher bleeding risk than did the lower dose regimen (2.4\% vs. $1.8 \%){ }^{36}$

In a dose-finding trial (Apixaban added to DAPT was evaluated in the Apixaban for Prevention of Acute Ischemic Events [APPRAISE], $n=1,715$ ), apixaban (from $2.5 \mathrm{mg}$ BID to $20 \mathrm{mg}$ OD) compared to placebo had a dose-dependent increase in the risk of clinically significant bleeding, but had a trend toward benefit for reducing ischemic events. ${ }^{37}$ However, in the phase III APPRAISE-2 trial $(n=7,392)$, apixaban $5 \mathrm{mg}(2.5 \mathrm{mg}$ with $\mathrm{CrCl}<40$ $\mathrm{mL} / \mathrm{min}$ ) BID compared to placebo significantly increased the risk of major bleeding (2.4\%/year vs. 0.9\%/year; $\mathrm{HR}, 2.59 ; 95 \% \mathrm{Cl}_{\text {, }}$ 1.50 to 4.46; $P=0.001$ ), and did not reduce composite of vascular death, $\mathrm{MI}$, or ischemic stroke (13.2\%/year vs. 14.0\%/year; HR, $0.95 ; 95 \% \mathrm{Cl}, 0.80$ to $1.11 ; P=0.51){ }^{38}$

In the phase III trials in ACS without AF, NOACs added to DAPT were associated with a higher risk of major bleeding. However, the European Medicines Agency approved the use of rivaroxaban $2.5 \mathrm{mg}$ BID added to standard antiplatelet therapy because ATLAS ACS 2-TIMI 51 showed benefits of low dose rivaroxaban regarding major ischemic events and vascular death. The European Society of Cardiology guidelines support this regimen in ACS patients with a low bleeding risk. ${ }^{29}$ However, the U.S. Food and Drug Administration did not approve the use of rivaroxaban in ACS without AF.

In contrast to earlier RCTs investigating NOACs added to DAPT, Randomized, Double-Blind, Double-Dummy, Active-controlled, Parallel-group, Multicenter Study to Compare the Safety of Rivaroxaban Versus Acetylsalicylic Acid in Addition to Either Clopidogrel or Ticagrelor Therapy in Subjects With Acute Coro- nary Syndrome (GEMINI-ACS- $1 ; n=3,037$ ) compared the safety of dual regimen with low-dose rivaroxaban $(2.5 \mathrm{mg} \mathrm{BID})$ plus $\mathrm{P}_{2} \mathrm{Y}_{12}$ inhibitor and aspirin plus $\mathrm{P}_{2} \mathrm{Y}_{12}$ inhibitor. During a median follow-up of 291 days, the rate of clinically significant bleeding not related to $C A B G$ was similar between the rivaroxaban and aspirin groups ( $5 \%$ vs. $5 \%$; $\mathrm{HR}, 1.09 ; 95 \% \mathrm{Cl}, 0.80$ to 1.50 ; $P=0.584)$. The risk of composite of vascular death, $\mathrm{Ml}$, stroke, or definite stent thrombosis (exploratory ischemic endpoint) was comparable between the rivaroxaban and aspirin groups (5\% vs. $5 \%$; $\mathrm{HR}, 1.06 ; 95 \% \mathrm{Cl}, 0.77$ to $1.46 ; P=0.732){ }^{39} \mathrm{GEMINI}-$ ACS-1 showed that dual therapy with NOAC plus $\mathrm{P}_{2} \mathrm{Y}_{12}$ inhibitor can be as safe as the standard DAPT. However, it was a phase II trial and not powered to fully assess the efficacy.

\section{Stable atherosclerotic vascular disease}

Cardiovascular Outcomes for People Using Anticoagulation Strategies (COMPASS; $n=27,395)$ compared combination therapy of rivaroxaban (2.5 mg BID) plus aspirin (100 mg OD), rivaroxaban alone (5 $\mathrm{mg} \mathrm{BID)}$, and aspirin alone (100 $\mathrm{mg}$ OD) in patients with stable atherosclerotic vascular disease (coronary artery disease or peripheral arterial disease)..$^{40}$ COMPASS was early terminated because of the superior efficacy of combination therapy over aspirin alone at the time of the first interim analysis when $50 \%$ of planned events had occurred. Combination therapy versus aspirin alone significantly reduced composite of cardiovascular death, stroke, or MI (primary efficacy outcome) during a mean follow-up of 23 months ( $4.1 \%$ versus $5.4 \% ; \mathrm{HR}, 0.76 ; 95 \% \mathrm{Cl}, 0.66$ to $0.86 ; P<0.001)$. The effect was consistent across diverse subgroups. Combination therapy versus aspirin alone was associated with a higher risk of major bleeding (3.1\% vs. 1.9\%; HR, 1.70; 95\% Cl, 1.40 to 2.05; $P<0.001)$, which was mainly driven by gastrointestinal (G-I) bleedings. The composite net-clinical-benefit outcome (cardiovascular death, stroke, MI, fatal bleeding, or symptomatic bleeding into a critical organ) occurred less with combination therapy than with aspirin alone (4.7\% vs. 5.9\%; HR, 0.80; 95\% $\mathrm{Cl}, 0.70$ to $0.91 ; P<0.001)$. All-cause death and vascular death were lower with combination therapy compared to aspirin alone. However, rivaroxaban $5 \mathrm{mg}$ BID alone had no significant benefit over aspirin alone in the primary efficacy outcome ( $4.9 \%$ vs. $5.4 \% ; \mathrm{HR}, 0.90 ; 95 \% \mathrm{Cl}, 0.79$ to $1.03 ; P=0.12$ ) and in the composite net-clinical-benefit outcome (5.5\% vs. $5.9 \%$; $\mathrm{HR}, 0.94 ; 95 \% \mathrm{Cl}, 0.84$ to $1.07 ; P=0.36$ ), but increased the risk of major bleeding (2.8\% vs. $1.9 \%$; $\mathrm{HR}, 1.51 ; 95 \% \mathrm{Cl}, 1.25$ to 1.84; $P<0.001)$.

Based on the COMPASS results, the U.S. Food and Drug Administration and the European Medicines Agency approved the 
$2.5 \mathrm{mg}$ BID dose of rivaroxaban in combination with aspirin in patients with stable coronary artery disease or peripheral arterial disease. In a subgroup analysis of patients with peripheral arterial disease, the benefit of combination therapy in patients with carotid stenosis $>50 \%$ or a history of carotid revascularization was consistent with those without carotid disease. ${ }^{41}$ However, COMPASS excluded patients with recent stroke, prior history of lacunar infarction, or prior history of intracerebral hemorrhage, and only 3.8\% of the enrolled patients had a history of prior stroke, ${ }^{40}$ which limits the application of the trial findings to stroke population.

\section{Acute coronary syndrome with atrial fibrillation}

In AF patients with ACS, DAPT is indicated for ACS and longterm oral anticoagulation is indicated for AF. Triple therapy with oral anticoagulation plus DAPT for 1 to 6 months is the standard antithrombotic therapy, but inevitably increases the risk of major bleeding. RCTs compared NOACs in combination with DAPT or $\mathrm{P}_{2} \mathrm{Y}_{12}$ inhibitor monotherapy vs. triple therapy with warfarin plus DAPT, primarily focusing on the risk of major bleedings rather than ischemic events.

Open-Label, Randomized, Controlled, Multicenter Study Exploring Two Treatment Strategies of Rivaroxaban, and a DoseAdjusted Oral Vitamin K Antagonist Treatment Strategy in Subjects with Atrial Fibrillation who Undergo Percutaneous Coronary Intervention (PIONEER AF-PCl; $n=2,124$ ) compared rivaroxaban $15 \mathrm{mg}$ OD plus $\mathrm{P}_{2} \mathrm{Y}_{12}$ inhibitor, rivaroxaban $2.5 \mathrm{mg}$ BID plus DAPT, and warfarin plus DAPT in patients with AF undergoing $\mathrm{PCl}^{42}$ Both the rivaroxaban-based regimens compared to warfarin plus DAPT reduced the risk of clinically-significant bleeding (primary endpoint) at 12 months: rivaroxaban $15 \mathrm{mg}$ OD plus $\mathrm{P}_{2} \mathrm{Y}_{12}$ inhibitor ( $16.8 \%$ vs. $26.7 \%$; $\mathrm{HR}, 0.59 ; 95 \% \mathrm{Cl}$, 0.47 to $0.76 ; P<0.001$ ) and rivaroxaban $2.5 \mathrm{mg}$ BID plus DAPT (18.0\% vs. 26.7\%; HR, $0.63 ; 95 \% \mathrm{Cl}, 0.50$ to $0.80 ; P<0.001$ ). The rate of composite of vascular death, Ml, or stroke did not differ across the three groups.

Randomized Evaluation of Dual Antithrombotic Therapy With Dabigatran vs. Triple Therapy With Warfarin in Patients With Nonvalvular Atrial Fibrillation Undergoing Percutaneous Coronary Intervention (RE-DUAL PCl; $n=2,725$ ) compared two dabigatran regimens (110 and $150 \mathrm{mg}$ BID) plus $\mathrm{P}_{2} \mathrm{Y}_{12}$ inhibitor monotherapy versus triple therapy with warfarin plus DAPT in patients with AF undergoing $\mathrm{PCl}{ }^{43}$ The primary endpoint of major or CRNM bleeding during a mean follow-up of 14 months was lower in the $110 \mathrm{mg}$ dabigatran plus $\mathrm{P}_{2} \mathrm{Y}_{12}$ inhibitor group than in the warfarin-based triple therapy group
(15.4\% vs. $26.9 \% ; \mathrm{HR}, 0.52 ; 95 \% \mathrm{Cl}, 0.42$ to $0.63 ; P<0.001$ for noninferiority; $P<0.001$ for superiority). The $150 \mathrm{mg}$ dabigatran plus $\mathrm{P}_{2} \mathrm{Y}_{12}$ inhibitor group also had a lower bleeding risk compared to the corresponding warfarin-based triple therapy group (20.2\% vs. $25.7 \%$; HR, $0.72 ; 95 \% \mathrm{Cl}, 0.58$ to $0.88 ; P<0.001$ for noninferiority; $P=0.002$ for superiority). Dabigatran-based dual therapy (two regimens combined) was not inferior to warfarinbased triple therapy for the composite efficacy endpoint of thromboembolic events (MI, stroke, or systemic embolism), death, or unplanned revascularization (13.7\% vs. $13.4 \%$; HR, $1.04 ; 95 \% \mathrm{Cl}, 0.84$ to $1.29 ; P=0.005$ for noninferiority). However, the sample size was not powered to adequately prove the noninferiority of each dabigatran regimen to triple therapy for the composite efficacy endpoint.

An Open-label, 2×2 Factorial, Randomized Controlled, Clinical Trial to Evaluate the Safety of Apixaban vs. Vitamin K Antagonist and Aspirin vs. Aspirin Placebo in Patients With Atrial Fibrillation and Acute Coronary Syndrome or Percutaneous Coronary Intervention (AUGUSTUS; $n=4,614$ ) was a $2 \times 2$ factorial trial (open-label comparison of apixaban $5 \mathrm{mg}$ [or $2.5 \mathrm{mg}$ if dose reduction is indicated] BID vs. warfarin and blinded comparison of aspirin vs. matching placebo) to assess the noninferiority of apixaban to warfarin and the superiority of placebo to aspirin for the primary outcome of major or CRNM bleeding in AF patients with $\mathrm{ACS}$ or $\mathrm{PCl}^{44}$ All patients received an approved $\mathrm{P}_{2} \mathrm{Y}_{12}$ inhibitor. The risk of major or CRNM bleeding for 6 months was lower with apixaban than with warfarin (10.5\% vs. $14.7 \%$; $\mathrm{HR}, 0.69 ; 95 \% \mathrm{Cl}, 0.58$ to $0.81 ; P<0.001$ for both noninferiority and superiority) and higher with aspirin versus placebo (16.1\% vs. $9.0 \%$; $\mathrm{HR}, 1.89$; $95 \% \mathrm{Cl}, 1.59$ to 2.24 ; $P<0.001)$. When the interventions were combined, the risk was highest with warfarin plus aspirin (18.7\%), followed by apixaban plus aspirin (13.8\%), warfarin alone (10.9\%), and apixaban alone (7.3\%). The risk of death or hospitalization was lower with apixaban versus warfarin ( $23.5 \%$ vs. $27.4 \%$; $H R, 0.83$; $95 \% \mathrm{Cl}, 0.74$ to $0.93 ; P=0.002$ for superiority), but was similar with aspirin versus placebo (26.2\% vs. 24.7\%; HR, 1.08; 95\% $\mathrm{Cl}, 0.96$ to 1.21). It was highest with warfarin plus aspirin $(27.5 \%)$ and lowest with apixaban alone (22.0\%). Another efficacy outcome of death or ischemic event did not differ between apixaban and warfarin and between aspirin and placebo. Overall, apixaban plus $\mathrm{P}_{2} \mathrm{Y}_{12}$ inhibitor monotherapy was the most favored regimen.

PIONEER AF-PCl, RE-DUAL PCl, and AUGUSTUS demonstrated the superiority of NOAC over warfarin for the risk of clinically significant bleeding in AF patients with ACS or PCl. The 2018 Joint European consensus document states that, as part of triple or dual therapy, NOACs are preferred options over oral 
vitamin $\mathrm{K}$ antagonist (VKA) in AF patients with ACS and/or undergoing PCl. ${ }^{45}$ The 2019 updated American College of Cardiology/American Heart Association/Heart Rhythm Society guidelines recommend NOACs, but there is no statement with regard to the preference of NOACs over warfarin. ${ }^{6}$ NOAC plus $\mathrm{P}_{2} \mathrm{Y}_{12}$ inhibitor monotherapy compared to NOAC-based or warfarinbased triple therapy does not appear to increase the risk of ischemic event. However, it should be noted that all the trials were not designed to primarily assess the efficacy of ischemic event outcome. Edoxaban Treatment vs. Vitamin K Antagonist in Patients With Atrial Fibrillation Undergoing Percutaneous Coronary Intervention (ENTRUST-AF-PCl; $n=1,500$ planned) is ongoing to compare endoxaban plus $\mathrm{P}_{2} \mathrm{Y}_{12}$ inhibitor and warfarin-based triple therapy (aspirin use for 1 to 12 months), primarily focusing on the risk of major or CRNM bleeding. ${ }^{46}$

\section{Chronic heart failure}

CHF, even with sinus rhythm, is associated with activation of thrombin-related pathways and increases the risk of thromboembolism. However, individual RCTs failed to show the benefit of warfarin over aspirin, and a meta-analysis indicated that warfarin versus aspirin was associated with lower risks of any stroke and ischemic stroke, but the benefit was offset by an increased risk of major bleeding. ${ }^{47}$ Given their better safety profile compared to warfarin, NOACs are promising options.

Study to Assess the Effectiveness and Safety of Rivaroxaban in Reducing the Risk of Death, Myocardial Infarction, or Stroke in Participants with Heart Failure and Coronary Artery Disease Following an Episode of Decompensated Heart Failure (COMMANDER-HF; $n=5,022)$ compared rivaroxaban $2.5 \mathrm{mg} \mathrm{BID}$ and placebo in addition to standard care (98.5\% of patients received single antiplatelet or DAPT) in CHF patients with a recent episode of worsening heart failure and coronary heart disease. During a median follow-up of 21 months, the rivaroxaban and placebo groups did not differ in the composite of all-cause death, $\mathrm{Ml}$, or stroke $(25.0 \%$ vs. $26.2 \%$; HR, $0.94 ; 95 \% \mathrm{Cl}, 0.84$ to $1.05 ; P=0.27)$ and the principal safety outcome of fatal bleeding or bleeding into a critical space $(0.7 \%$ vs. $0.9 \%$; $H R$, $0.80 ; 95 \% \mathrm{Cl}, 0.43$ to $1.49 ; P=0.48)$. Heart failure-related deaths rather than thromboembolic events constituted a large proportion of clinical events, which likely accounts for the lack of anticoagulation benefit in this study population. ${ }^{48}$ In a post hoc analysis, a newly defined thromboembolic composite ( $\mathrm{MI}$, ischemic stroke, sudden/unwitnessed death, symptomatic VTE) was lower with rivaroxaban than with placebo. ${ }^{49}$ Therefore, future NOAC trials in CHF should be designed to target thromboembolic events.

\section{Deep vein thrombosis prophylaxis after hip or knee arthroplasty}

Patients undergoing total hip arthroplasty (THA) or total knee arthroplasty (TKA) are at high risk of VTE including deep vein thrombosis (DVT) and pulmonary embolism (PE), and anticoagulation therapy during the high risk period is recommended. ${ }^{50}$

Four RCTs compared dabigatran (150 mg or $220 \mathrm{mg}$ OD) and enoxaparin (40 mg OD or $30 \mathrm{mg} B I D$ ) in patients undergoing THA or TKA (Table 1). ${ }^{7,851,52}$ Three trials showed non-inferiority of dabigatran to enoxaparin for preventing VTE or all-cause death. ${ }^{7,852} \mathrm{~A}$ pooled analysis demonstrated that dabigatran 220 $\mathrm{mg} O \mathrm{D}$ and $150 \mathrm{mg} \mathrm{OD}$ versus enoxaparin were comparable for preventing major VTE or VTE-related death $(3.0 \%$ and $3.8 \%$ vs. $3.3 \%)$ and for the risk of major bleeding $(1.4 \%$ and $1.1 \%$ vs. $1.4 \%)^{53}$

The REgulation of Coagulation in ORthopedic Surgery to Prevent DVT and PE, Controlled, Double-blind, Randomized Study of BAY 59-7939 in the Extended Prevention of VTE in Patients Undergoing Elective Total Hip Replacement (RECORD) 1 $(n=4,541), 2(n=2,509), 3(n=2,531)$, and $4(n=3,148)$ trials compared rivaroxaban (10 $\mathrm{mg} \mathrm{OD}$ ) and enoxaparin (40 mg OD or $30 \mathrm{mg} B I D)$ in patients undergoing THA or TKA. ${ }^{9-11,54}$ All the RECORD trials showed the superior efficacy of rivaroxaban over

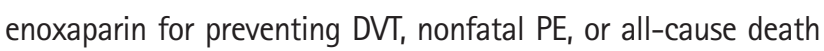
without increasing major bleeding events. In a pooled analysis, rivaroxaban versus enoxaparin significantly reduced the composite of symptomatic VTE and all-cause death $(0.6 \%$ vs. $1.3 \%$; HR, $0.42 ; 95 \% \mathrm{Cl}, 0.29$ to 0.63$)$, and did not significantly increase the risk of major or CRNM (2.8\% vs. $2.5 \%, P=0.19){ }^{55}$

The Apixaban Dose Orally vs. Anticoagulation with Enoxaparin (ADVANCE) $1(n=3,195), 2(n=3,057), 3 \quad(n=3,866)$ trials compared apixaban (2.5 mg BID) versus enoxaparin ( $30 \mathrm{mg}$ BID or $40 \mathrm{mg}$ OD) in patients with TKA or THA. ${ }^{56-58}$ Compared to enoxaparin $30 \mathrm{mg} \mathrm{BID}$, apixaban was not noninferior, albeit comparable, for the risk of total VTE or all-cause death, but had less major or CRNM bleeding. ${ }^{56}$ When compared to exoxaparin $40 \mathrm{mg} \mathrm{OD}$, apixaban was more effective for preventing total VTE or all-cause death without a significant increase in the risk of major or CRNM bleeding..$^{57,58}$

In two trials (Studying Thrombosis After Replacement Surgery [STARS] E-3 [ $n=716]$ and STARS J-V [ $n=610]$ ) enrolling East Asian patients with TKA or THA, edoxaban $30 \mathrm{mg}$ OD versus enoxaparin $20 \mathrm{mg}$ BID was more effective for preventing symptomatic PE or asymptomatic and symptomatic DVT without significantly increasing major or CRNM bleedings for 11 to 14 days. ${ }^{59,60}$ In a pooled analysis, edoxaban versus enoxaparin had a lower VTE risk $(5.1 \%$ vs. $10.7 \%, P<0.001)$ and a similar 
major or CRNM bleeding risk (4.6\% vs. 3.7\%, $P=0.427) .{ }^{61}$

The 9th American College of Chest Physicians guidelines recommend thromboprophylaxis for a minimum of 10 to 14 days and extension in the outpatient period up to 35 days after surgery in patients undergoing THA or TKA. For anticoagulation therapy, use of dabigatran, rivaroxaban, or apixaban as well as low-molecular weight heparin (LMWH), fondaparinux, or VKA is recommended. ${ }^{50}$

\section{Acute venous thromboembolism}

VTE is a serious life-threatening condition, and anticoagulation is the mainstay for acute management and long-term prevention of recurrent VTE. RCTs in patients with VTE have focused to demonstrate better safety and similar efficacy of NOACs compared to conventional anticoagulation therapy of parenteral anticoagulation switched to warfarin.

In Phase III, Randomised, Double Blind, Parallel-group Study of the Efficacy and Safety of Oral Dabigatran Etexilate $150 \mathrm{mg}$ Twice Daily Compared to Warfarin (INR 2.0-3.0) for 6 Month Treatment of Acute Symptomatic Venous Thromboembolism, Following Initial Treatment (5-10 Days) With a Parenteral Anticoagulant Approved for This Indication (RE-COVER; $n=2,564$ ) and RE-COVER II $(n=2,589)$, dabigatran $150 \mathrm{mg}$ BID versus warfarin (parenteral anticoagulation at least 5 days in both treatments) was not inferior for preventing recurrent VTE or VTE-related death, and had a comparable risk of major bleeding for 6 months in patients with acute, symptomatic proximal DVT or PE.62,63 In a pooled analysis, dabigatran versus warfarin was comparable for preventing recurrent VTE or VTE-related death (2.4\% vs. $2.2 \% ; \mathrm{HR}, 1.09 ; 95 \% \mathrm{Cl}, 0.76$ to 1.57$)$ and for the risk of major bleeding (1.4\% vs. $2.0 \% ; \mathrm{HR}, 0.73 ; 95 \% \mathrm{Cl}$, 0.48 to 1.11 ), but had less major or CRNM bleedings (5.3\% vs. $8.5 \%$; $\mathrm{HR}, 0.62 ; 95 \% \mathrm{Cl}, 0.50$ to 0.76$){ }^{63}$

Twice-daily Oral Direct Thrombin Inhibitor Dabigatran Etexilate in the Long-term Prevention of Recurrent Symptomatic Proximal Venous Thromboembolism in Patients With Symptomatic Deep-vein Thrombosis or Pulmonary Embolism (RESONATE; placebo-control study, $n=1,353$ ) and Twice-daily Oral Direct Thrombin Inhibitor Dabigatran Etexilate in the Long Term Prevention of Recurrent Symptomatic VTE (RE-MEDY; active-control study with warfarin, $n=2,866$ ) evaluated the extended use of dabigatran $150 \mathrm{mg}$ BID for 3 to 36 months in patients who had already completed 3-month anticoagulation therapy. ${ }^{64}$ Dabigatran versus placebo significantly reduced the risk of recurrent symptomatic VTE (0.4\% vs. $5.6 \%$; HR, 0.08 ; $95 \% \mathrm{Cl}, 0.02$ to $0.25 ; P<0.001)$, but was associated with more major or CRNM bleedings (5.3\% vs. $1.8 \%$; $\mathrm{HR}, 2.92 ; 95 \% \mathrm{Cl}$,
1.52 to $5.60 ; P=0.001)$. When compared to warfarin, dabigatran was comparable for preventing recurrent symptomatic VTE (1.8\% vs. $1.3 \% ; \mathrm{HR}, 1.44 ; 95 \% \mathrm{Cl}, 0.78$ to 2.64$)$, but had a lower risk of major or CRNM bleeding (5.6\% vs. $10.2 \%$; HR, $0.54 ; 95 \% \mathrm{Cl}, 0.41$ to $0.71 ; P<0.001)$.

In Oral Direct Factor Xa Inhibitor Rivaroxaban in Patients With Acute Symptomatic Deep-Vein Thrombosis or Pulmonary Embolism (EINSTEIN)-DVT ( $n=3,449$, patients with acute symptomatic DVT) and EINSTEIN-PE ( $n=4,832$, patients with acute symptomatic PE), ${ }^{65,66}$ rivaroxaban alone (15 mg BID for 3 weeks and then $20 \mathrm{mg}$ OD without enoxaparin bridging) versus warfarin bridging with enoxaparin was not inferior for preventing recurrent symptomatic VTE (EINSTEIN-DVT: 2.1\% vs. 3.0\%; HR, $0.68 ; 95 \% \mathrm{Cl}, 0.44$ to $1.04 ; P<0.001$ for noninferiority; and EINSTEIN-PE: $2.1 \%$ vs. $1.8 \% ; \mathrm{HR}, 1.12 ; 95 \% \mathrm{Cl}, 0.75$ to 1.68 ; $P=0.003$ for noninferiority), and was comparable for the risk of major or CRNM bleeding (EINSTEIN-DVT: $8.1 \%$ vs. 8.1\%; HR, 0.97; $95 \% \mathrm{Cl}, 0.76$ to $1.22 ; P=0.77$; and EINSTEIN-PE: $10.3 \%$ vs. $11.4 \%$; $\mathrm{HR}, 0.90 ; 95 \% \mathrm{Cl}, 0.76$ to $1.07 ; P=0.23$ ). In EINSTEIN-PE, major bleedings were less frequent with rivaroxaban (1.1\% vs. 2.2\%; HR, $0.49 ; 95 \% \mathrm{Cl}, 0.31$ to $0.79 ; P=0.003$ ).

EINSTEIN-extension $(n=1,197)$ assessed the extended use of rivaroxaban $20 \mathrm{mg}$ OD for 6 or 12 months in patients with prior anticoagulation therapy for 6 to 12 months after acute symptomatic DVT or PE and equipoise for continued anticoagulation. ${ }^{65}$ Rivaroxaban versus placebo significantly reduced the risk of recurrent VTE (1.3\% vs. 7.1\%; HR, $0.18 ; 95 \% \mathrm{Cl}, 0.09$ to $0.39 ; P<0.001)$. The increased risk with rivaroxaban was not significant for major bleedings ( $0.7 \%$ vs. $0 \%, P=0.11)$, but was significant for major or CRNM bleeding (6.0\% vs. 1.2\%; HR, 5.19; 95\% $\mathrm{Cl}, 2.3$ to $11.7 ; P<0.001)$.

In Apixaban for the Initial Management of Pulmonary Embolism and Deep-Vein Thrombosis as First-Line Therapy (AMPLIFY; $n=5,244$ ), apixaban alone (10 mg BID for 7 days followed by 5 $\mathrm{mg}$ BID for 6 months) versus warfarin bridging with enoxaparin in patients with acute VTE was not inferior for preventing recurrent symptomatic VTE (2.3\% vs. 2.7\%; RR, 0.84; 95\% Cl, 0.60 to $1.18 ; P<0.001$ for noninferiority), and had a lower risk of major bleeding $(0.6 \%$ vs. $1.8 \%$; $R R, 0.31 ; 95 \% \mathrm{Cl}, 0.17$ to 0.55; $P<0.001) .{ }^{67}$ In AMPLIFY-EXT $(n=2,486)$ enrolling patients with prior anticoagulation for 6 to 12 months and equipoise for continued anticoagulation, two apixaban regimens (apixaban $5 \mathrm{mg}$ BID and $2.5 \mathrm{mg}$ BID) versus placebo for 12 months were superior for preventing recurrent VTE or all-cause death (5 mg regimen: $4.2 \%$ vs. $11.6 \%$; $\mathrm{RR}, 0.36 ; 95 \% \mathrm{Cl}, 0.25$ to 0.53 ; $P<0.001$; and $2.5 \mathrm{mg}$ regimen: $3.8 \%$ vs. $11.6 \%$; RR, $0.33 ; 95 \%$ $\mathrm{Cl}, 0.22$ to $0.48 ; P<0.001)$. The three groups had comparable risks of major bleeding ( $0.1 \%$ vs. $0.2 \%$ vs. $0.5 \%)$ and major or 
CRNM bleeding (4.3\% vs. $3.2 \%$ vs. $2.7 \%$ ). ${ }^{68}$

In Phase 3, Randomized, Parallel-Group, Multi-Center, MultiNational Study for the Evaluation of Efficacy and Safety of Heparin/Edoxaban Versus Heparin/Warfarin in Subjects With Symptomatic Deep-Vein Thrombosis and or Pulmonary Embolism (Hokusai-VTE; $n=8,292$ ), edoxaban 60 mg (30 mg for $\mathrm{CrCL}$ 30 to $50 \mathrm{~mL} / \mathrm{min}$ or body weight $<60 \mathrm{~kg}$ ) OD versus warfarin (parenteral anticoagulation at least 5 days in both treatments) for 3 to 12 months in patients with acute symptomatic DVT or PE was not inferior for preventing symptomatic recurrent VTE (3.2\% vs. 3.5\%; $\mathrm{HR}, 0.89 ; 95 \% \mathrm{Cl}, 0.70$ to $1.13 ; P<0.001$ for noninferiority), and had a lower risk of major or CRNM bleeding $(8.5 \%$ vs. $10.3 \%$; $\mathrm{HR}, 0.81 ; 95 \% \mathrm{Cl}, 0.71$ to $0.94 ; P=0.004$ for superiority). ${ }^{69}$

RCTs in acute VTE demonstrated that NOACs compared to conventional anticoagulation strategy had a similar efficacy and a comparable or better safety. Extended use of NOACs reduced recurrent VTE at the cost of more major bleedings compared to placebo, and reduced the risk of major bleeding with a similar efficacy compared to warfarin. The American College of Chest Physicians and European Society of Cardiology guidelines recommend NOACs over warfarin in patients with VTE not associated with cancer. ${ }^{70,71}$

\section{Venous thromboembolism related to active cancer}

Patients with cancer have a 7-fold increased risk of VTE compared to individuals without cancer. ${ }^{72}$ RCTs showed that LMWHs were more effective than and as safe as VKAs. Despite of their convenient administration and predictable effects, NOACs in cancer patients have disadvantages of (1) limited evidence from RCTs, (2) absorption affected by vomiting, a common symptom in cancer patients, and (3) drug interactions with chemotherapy agents. The 2016 CHEST guidelines recommend extended anticoagulant therapy (no scheduled stop date) over 3 months and suggest LMWHs over NOACs for anticoagulation therapy. ${ }^{70}$ After then, several RTCs have been published.

Hokusai-VTE cancer $(n=1,050)$ in patients with cancer and acute symptomatic or incidentally detected VTE showed that edoxaban (60 mg OD after LMWH for at least 5 days) versus dalteparin (200 IU/kg OD for 1 month followed by $150 \mathrm{lU} / \mathrm{kg}$ OD) was not inferior for preventing recurrent VTE or major bleeding during 12 months (12.8\% vs. $13.5 \%$; $\mathrm{HR}, 0.97 ; 95 \% \mathrm{Cl}, 0.70$ to 1.36; $P=0.006$ for noninferiority; $P=0.87$ for superiority): recurrent VTEs (7.9\% vs. $11.3 \%$; $\mathrm{HR}, 0.71 ; 95 \% \mathrm{Cl}, 0.48$ to 1.06 ; $P=0.09$ ) and major bleedings (6.9\% vs. 4.0\%; $\mathrm{HR}, 1.77 ; 95 \% \mathrm{Cl}_{\text {, }}$ 1.03 to $3.04 ; P=0.04)$. More major bleedings with edoxaban was caused by more G-I bleedings in G-I cancer patients. ${ }^{73}$

In Anticoagulation therapy in SELECTeD cancer patients at risk of recurrence of venous thromboembolism (SELECT-D; $\mathrm{n}=406$ ), rivaroxaban (15 mg BID for 3 weeks and then $20 \mathrm{mg}$ OD) versus dalteparin (200 IU/kg daily for 1 month and then $150 \mathrm{IU} / \mathrm{kg}$ daily) in patients with active cancer and VTE reduced the risk of recurrent VTE (4\% vs. 11\%; HR, 0.43; 95\% Cl, 0.19 to 0.99 ), but increased major bleeding events nonsignificantly (6\% vs. 4\%; HR, 1.83; 95\% Cl, 0.68 to 4.96) and CRNM significantly (13\% vs. 4\%; HR, 3.76; 95\% Cl, 1.63 to 8.69). The higher bleeding risk with rivaroxaban was largely driven by more G-I bleedings in G-I cancer patients. ${ }^{74}$

In Apixaban and dalteparin in active malignancy associated venous thromboembolism (ADAM VTE; $n=300$ ), apixaban (10 mg BID for 7 days followed by $5 \mathrm{mg}$ BID) versus dalteparin (200 IU/kg daily for 1 month followed by $150 \mathrm{lU} / \mathrm{kg}$ daily) in patients with active cancer and confirmed VTE was superior for preventing recurrent VTE for 6 months (3.4\% vs. 14.1\%; HR, $0.26 ; 95 \% \mathrm{Cl}, 0.09$ to $0.80 ; P=0.0182$ ). There were no major bleeding with apixaban and 3 (2.1\%) with dalteparin. ${ }^{75,76}$

In the 2018 updated National Comprehensive Cancer Network guidelines, edoxaban after parenteral anticoagulation for 5 to 10 days is newly listed as a category 1 recommendation. Apixaban monotherapy, rivaroxaban monotherapy, and dabigatran combined with at least 5 days of parenteral anticoagulation are recommended as alternatives for patients with compelling reasons to avoid LMWHs. ${ }^{77}$ However, physicians should recognize the bleeding risk of NOCAs in patients with G-I cancer and the effect of vomiting and chemotherapeutic agents on the effect of NOACs.

\section{Acute medical illness at high risk of venous thromboembolism}

Patients who are hospitalized and immobilized for acute medical illness are at increased risk of VTE. Low dose parenteral anticoagulation for 6 to 14 days is recommended by guidelines. ${ }^{78}$ The risk of VTE persists during the first month after discharge, but earlier RCTs failed to show the benefit of extended use of enoxaparin, rivaroxaban, or apixaban. ${ }^{79-81}$ Recently, in Acute Medically III VTE Prevention with Extended Duration Betrixaban (APEX; $n=7,513$ ) for patients with acute medical illness (acutely decom-

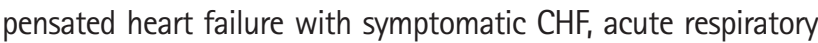
failure in patients with chronic symptomatic lung disease, acute infection without septic shock, acute rheumatic disorders, or acute ischemic stroke) and at high risk of VTE (reduced mobility and specific risk factors based on age, D-dimer level and history of either VTE or cancer), the extended use of betrixaban for 35 to 
42 days (after enoxaparin for 6 to 14 days) vs. standard of care (enoxaparin for 6 to 14 days) reduced the risk of asymptomatic proximal DVT, symptomatic VTE, or VTE-related death (5.3\% vs. $7.0 \% ; \mathrm{RR}, 0.76 ; 95 \% \mathrm{Cl}, 0.63$ to $0.92 ; P=0.006$ ) without increasing major bleeding events ( $0.7 \%$ vs. $0.6 \%$; $\mathrm{RR}, 1.19 ; 95 \% \mathrm{Cl}, 0.67$ to $2.12 ; P=0.55){ }^{82}$ Based on these results, betrixaban was approved for this indication by the U.S. Food and Drug Administration. In a subsequent analysis, the extended betrixaban use was associated with a lower risk of all stroke $(0.54 \%$ vs. $0.97 \%$; $R R$, $0.56 ; 95 \% \mathrm{Cl}, 0.32$ to $0.96 ; P=0.032)$ and ischemic stroke $(0.48 \%$ vs. $0.91 \% ; \mathrm{RR}, 0.53 ; 95 \% \mathrm{Cl}, 0.30$ to $0.94 ; P=0.026){ }^{83}$

\section{Antiphospholipid antibody syndrome}

Antiphospholipid antibody (Ab) syndrome, diagnosed by at least one thrombotic events or pregnancy-related complications and at least two positive antiphospholipid Ab tests confirmed by follow-up tests, are at high risk of recurrent thrombotic event. The risk is highest in patients with positivity on all three Ab tests (lupus anticoagulant, anticardiolipin $\mathrm{Ab}$, and anti-b2-glycoprotein I Ab), up to 6\% to $13 \%$ per year. Trial on Rivaroxaban in AntiPhospholipid Syndrome (TRASP) compared rivaroxaban and warfarin in patients with a history of proven venous or arterial thrombosis and positive for all three antiphospholipid Ab tests. The trial was early terminated after enrolling 120 patients (64\% with venous thrombosis, 21\% with arterial thrombosis [13\% with stroke], and $15 \%$ with venous and arterial thrombosis) because the rivaroxaban group versus the warfarin group had a higher risk of the composite of thromboembolic events, major bleeding, or vascular death (19\% vs. $3 \%$; $\mathrm{HR}, 6.7 ; 95 \% \mathrm{Cl}, 1.5$ to 30.5$)$ during a mean follow-up of 596 days. Seven thromboembolic events (four ischemic strokes and three Mls) occurred in the rivaroxaban group, but none in the warfarin group. Major bleeding was more common with rivaroxaban versus warfarin (4 events [7\%] vs. 2 events [3\%]]. ${ }^{84}$

\section{Conclusions}

Large clinical trials have provided the evidential foundation for the use of NOACs in DVT prophylaxis with hip or knee arthroplasty, acute and long-term management of VTE with or without cancer, and concomitant ACS and AF. Although debate still remains, very low dose rivaroxaban added to standard antiplatelet therapy was beneficial in patients with ACS without $\mathrm{AF}$ and those with stable cardiovascular disease. Physicians should acknowledge the NOAC regimen with proven efficacy applicable to individual medical conditions. For secondary stroke prevention, the trial results, up to now, do not support the use of NOACs in ESUS. For other potential candidates of PFO-related stroke, acute ischemic stroke, and CVT, high quality evidence is lacking. Lessons from the earlier successful and unsuccessful trials can guide the optimal future trial design for NOACs in secondary stroke prevention.

\section{Disclosure}

Dr. Keun-Sik Hong has received lecture honoraria and research grants from Daiichi-Sankyo Korea, Pfizer Korea, Bristol-Myers Squibb Korea, Boehringer Ingelheim Korea, Bayer Korea from related to the current topic.

\section{References}

1. Connolly SJ, Ezekowitz MD, Yusuf S, Eikelboom J, Oldgren J,

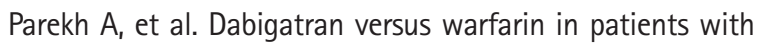
atrial fibrillation. N Engl J Med 2009;361:1139-1151.

2. Connolly SJ, Eikelboom J, Joyner C, Diener HC, Hart R, Golitsyn $S$, et al. Apixaban in patients with atrial fibrillation. $N$ Engl J Med 2011;364:806-817.

3. Patel MR, Mahaffey KW, Garg J, Pan G, Singer DE, Hacke W, et al. Rivaroxaban versus warfarin in nonvalvular atrial fibrillation. N Engl J Med 2011;365:883-891.

4. Giugliano RP, Ruff CT, Braunwald E, Murphy SA, Wiviott SD, Halperin $J L_{\text {, et }}$ al. Edoxaban versus warfarin in patients with atrial fibrillation. N Engl J Med 2013;369:2093-2104.

5. Kirchhof $P$, Benussi $S$, Kotecha D, Ahlsson A, Atar D, Casadei $B$, et al. 2016 ESC guidelines for the management of atrial fibrillation developed in collaboration with EACTS. Eur Heart J 2016;37:2893-2962.

6. January CT, Wann LS, Calkins H, Chen LY, Cigarroa JE, Cleveland JC Jr, et al. 2019 AHA/ACC/HRS focused update of the 2014 AHA/ACC/HRS guideline for the management of patients with atrial fibrillation: a report of the American College of Cardiology/American Heart Association Task Force on Clinical Practice Guidelines and the Heart Rhythm Society. J Am Coll Cardiol 2019;74:104-132.

7. Eriksson BI, Dahl OE, Rosencher N, Kurth AA, van Dijk CN, Frostick SP, et al. Dabigatran etexilate versus enoxaparin for prevention of venous thromboembolism after total hip replacement: a randomised, double-blind, non-inferiority trial. Lancet 2007;370:949-956.

8. Eriksson $\mathrm{BI}, \mathrm{Dahl} \mathrm{OE}$, Rosencher $\mathrm{N}$, Kurth $\mathrm{AA}$, van Dijk $C N$, Frostick SP, et al. Oral dabigatran etexilate vs. subcutaneous enoxaparin for the prevention of venous thromboembolism after total knee replacement: the RE-MODEL randomized trial. J Thromb Haemost 2007;5:2178-2185. 
9. Eriksson BI, Borris LC, Friedman RJ, Haas S, Huisman MV, Kakkar AK, et al. Rivaroxaban versus enoxaparin for thromboprophylaxis after hip arthroplasty. N Engl J Med 2008;358:27652775.

10. Kakkar AK, Brenner B, Dahl OE, Eriksson BI, Mouret P, Muntz $J$, et al. Extended duration rivaroxaban versus short-term enoxaparin for the prevention of venous thromboembolism after total hip arthroplasty: a double-blind, randomized controlled trial. Lancet 2008;372:31-39.

11. Lassen MR, Ageno W, Borris LC, Lieberman JR, Rosencher N, Bandel TJ, et al. Rivaroxaban versus enoxaparin for thromboprophylaxis after total knee arthroplasty. N Engl J Med 2008;358: 2776-2786.

12. Hart RG, Diener HC, Coutts SB, Easton JD, Granger CB, O'Donnell $\mathrm{MJ}$, et al. Embolic strokes of undetermined source: the case for a new clinical construct. Lancet Neurol 2014;13:429-438.

13. Hart RG, Sharma M, Mundl H, Kasner SE, Bangdiwala SI, Berkowitz SD, et al. Rivaroxaban for stroke prevention after embolic stroke of undetermined source. N Engl J Med 2018;378:21912201.

14. Diener HC, Sacco RL, Easton JD, Granger CB, Bernstein RA, Uchiyama $\mathrm{S}$, et al. Dabigatran for prevention of stroke after embolic stroke of undetermined source. N Engl J Med 2019;380:19061917.

15. Kamel H, Longstreth WT Jr, Tirschwell DL, Kronmal RA, Broderick JP, Palesch YY, et al. The AtRial cardiopathy and antithrombotic drugs in prevention after cryptogenic stroke randomized trial: rationale and methods. Int J Stroke 2019;14:207-214.

16. Geisler T, Poli S, Meisner C, Schreieck J, Zuern CS, Nägele T, et al. Apixaban for treatment of embolic stroke of undetermined source (ATTICUS randomized trial): rationale and study design. Int J Stroke 2017;12:985-990.

17. Ntaios G, Swaminathan B, Berkowitz SD, Gagliardi RJ, Lang

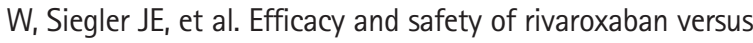
aspirin in embolic stroke of undetermined source and carotid atherosclerosis. Stroke 2019;50:2477-2485.

18. Mas JL, Derumeaux G, Guillon B, Massardier E, Hosseini $H$, Mechtouff $L$, et al. Patent foramen ovale closure or anticoagulation vs. antiplatelets after stroke. N Engl J Med 2017;377: 1011-1021.

19. Kasner SE, Swaminathan B, Lavados P, Sharma M, Muir K, Veltkamp $R$, et al. Rivaroxaban or aspirin for patent foramen ovale and embolic stroke of undetermined source: a prespecified subgroup analysis from the NAVIGATE ESUS trial. Lancet Neurol 2018;17:1053-1060.

20. Saposnik G, Barinagarrementeria F, Brown RD Jr, Bushnell $C D$, Cucchiara $B$, Cushman $M$, et al. Diagnosis and management of cerebral venous thrombosis: a statement for health- care professionals from the American Heart Association/ American Stroke Association. Stroke 2011;42:1158-1192.

21. Geisbüsch $C$, Richter $D$, Herweh $C$, Ringleb PA, Nagel $S$. Novel factor $X a$ inhibitor for the treatment of cerebral venous and sinus thrombosis: first experience in 7 patients. Stroke 2014;45: 2469-2471.

22. Mendonça MD, Barbosa R, Cruz-e-Silva V, Calado S, VianaBaptista M. Oral direct thrombin inhibitor as an alternative in the management of cerebral venous thrombosis: a series of 15 patients. Int J Stroke 2015;10:1115-1118.

23. Rao SK, Ibrahim M, Hanni CM, Suchdev K, Parker D, Rajamani $K$, et al. Apixaban for the treatment of cerebral venous thrombosis: a case series. J Neurol Sci 2017;381:318-320.

24. Wasay M, Khan M, Rajput HM, Farooq S, Memon MI, AIRukn $S A$, et al. New oral anticoagulants versus warfarin for cerebral venous thrombosis: a multi-center, observational study. J Stroke 2019;21:220-223.

25. Ferro JM, Bousser MG, Canhão P, Coutinho JM, Crassard I, Dentali $F$, et al. European Stroke Organization guideline for the diagnosis and treatment of cerebral venous thrombosis: endorsed by the European Academy of Neurology. Eur Stroke J 2017;2:195-221.

26. Ferro JM, Dentali F, Coutinho JM, Kobayashi A, Caria J, Desch $M$, et al. Rationale, design, and protocol of a randomized controlled trial of the safety and efficacy of dabigatran etexilate versus dose-adjusted warfarin in patients with cerebral venous thrombosis. Int J Stroke 2018;13:766-770.

27. Kate M, Gioia L, Buck B, Sivakumar L, Jeerakathil T, Shuaib $A$, et al. Dabigatran therapy in acute ischemic stroke patients without atrial fibrillation. Stroke 2015;46:2685-2687.

28. Ng KH, Sharma M, Benavente O, Gioia L, Field TS, Hill MD, et al. Dabigatran following acute transient ischemic attack and minor stroke II (DATAS II). Int J Stroke 2017;12:910-914.

29. Ibanez B, James S, Agewall S, Antunes MJ, Bucciarelli-Ducci

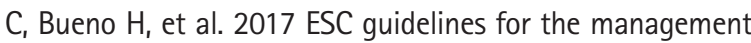
of acute myocardial infarction in patients presenting with ST-segment elevation: the task force for the management of acute myocardial infarction in patients presenting with STsegment elevation of the European Society of Cardiology (ESC). Eur Heart J 2018;39:119-177.

30. Amsterdam EA, Wenger NK, Brindis RG, Casey DE Jr, Ganiats TG, Holmes DR Jr, et al. 2014 AHA/ACC guideline for the management of patients with non-ST-elevation acute coronary syndromes: a report of the American College of Cardiology/American Heart Association Task Force on Practice Guidelines. Circulation 2014;130:e344-e426.

31. Réganon E, Vila V, Martínez-Sales V, Vaya A, Aznar J. Inflammation, fibrinogen and thrombin generation in patients with 
previous myocardial infarction. Haematologica 2002;87:740745.

32. Ardissino D, Merlini PA, Bauer KA, Galvani M, Ottani F, Fran-

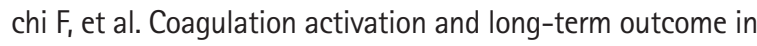
acute coronary syndromes. Blood 2003;102:2731-2735.

33. Christersson C, Oldgren J, Bylock A, Wallentin L, Siegbahn A. Long-term treatment with ximelagatran, an oral direct thrombin inhibitor, persistently reduces the coagulation activity after a myocardial infarction. J Thromb Haemost 2005;3:22452253.

34. Oldgren J, Budaj A, Granger CB, Khder Y, Roberts J, Siegbahn $A$, et al. Dabigatran vs. placebo in patients with acute coronary syndromes on dual antiplatelet therapy: a randomized, double-blind, phase II trial. Eur Heart J 2011;32:2781-2789.

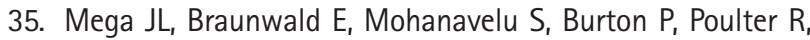
Misselwitz F, et al. Rivaroxaban versus placebo in patients with acute coronary syndromes (ATLAS ACS-TIMI 46): a randomised, double-blind, phase II trial. Lancet 2009;374:29-38.

36. Mega JL, Braunwald E, Wiviott SD, Bassand JP, Bhatt DL, Bode $C_{\text {, et }}$ al. Rivaroxaban in patients with a recent acute coronary syndrome. N Engl J Med 2012;366:9-19.

37. APPRAISE Steering Committee and Investigators, Alexander JH, Becker RC, Bhatt DL, Cools F, Crea F, et al. Apixaban, an oral, direct, selective factor $\mathrm{Xa}$ inhibitor, in combination with antiplatelet therapy after acute coronary syndrome: results of the Apixaban for Prevention of Acute Ischemic and Safety Events (APPRAISE) trial. Circulation 2009;119:2877-2885.

38. Alexander JH, Lopes RD, James $\mathrm{S}$, Kilaru R, He Y, Mohan P, et al. Apixaban with antiplatelet therapy after acute coronary syndrome. N Engl J Med 2011;365:699-708.

39. Ohman EM, Roe MT, Steg PG, James SK, Povsic TJ, White J, et al. Clinically significant bleeding with low-dose rivaroxaban versus aspirin, in addition to P2Y12 inhibition, in acute coronary syndromes (GEMINI-ACS-1): a double-blind, multicentre, randomised trial. Lancet 2017;389:1799-1808.

40. Eikelboom JW, Connolly SJ, Bosch J, Dagenais GR, Hart RG, Shestakovska 0, et al. Rivaroxaban with or without aspirin in stable cardiovascular disease. N Engl J Med 2017;377:13191330.

41. Anand SS, Bosch J, Eikelboom JW, Connolly SJ, Diaz R, Widimsky $P$, et al. Rivaroxaban with or without aspirin in patients with stable peripheral or carotid artery disease: an international, randomised, double-blind, placebo-controlled trial. Lancet 2018;391:219-229.

42. Gibson CM, Mehran R, Bode C, Halperin J, Verheugt FW, Wildgoose $\mathrm{P}$, et al. Prevention of bleeding in patients with atrial fibrillation undergoing PCI. N Engl J Med 2016;375:2423-2434.

43. Cannon CP, Bhatt DL, Oldgren J, Lip GYH, Ellis SG, Kimura T, et al. Dual antithrombotic therapy with dabigatran after $\mathrm{PCl}$ in atrial fibrillation. N Engl J Med 2017;377:1513-1524.

44. Lopes RD, Heizer G, Aronson R, Vora AN, Massaro T, Mehran R, et al. Antithrombotic therapy after acute coronary syndrome or PCl in atrial fibrillation. N Engl J Med 2019;380:1509-1524.

45. Lip GYH, Collet JP, Haude M, Byrne R, Chung EH, Fauchier $L$, et al. 2018 Joint European consensus document on the management of antithrombotic therapy in atrial fibrillation patients presenting with acute coronary syndrome and/or undergoing percutaneous cardiovascular interventions: a joint consensus document of the European Heart Rhythm Association (EHRA), European Society of Cardiology Working Group on Thrombosis, European Association of Percutaneous Cardiovascular Interventions (EAPCI), and European Association of Acute Cardiac Care (ACCA) endorsed by the Heart Rhythm Society (HRS), Asia-Pacific Heart Rhythm Society (APHRS), Latin America Heart Rhythm Society (LAHRS), and Cardiac Arrhythmia Society of Southern Africa (CASSA). Europace 2019;21:192-193.

46. Vranckx $P$, Lewalter $T$, Valgimigli M, Tijssen JG, Reimitz PE, Eckardt $L$, et al. Evaluation of the safety and efficacy of an edoxaban-based antithrombotic regimen in patients with atrial fibrillation following successful percutaneous coronary intervention $(\mathrm{PCl})$ with stent placement: rationale and design of the ENTRUST-AF PCI trial. Am Heart J 2018;196:105-112.

47. Lee M, Saver JL, Hong KS, Wu HC, Ovbiagele B. Risk-benefit profile of warfarin versus aspirin in patients with heart failure and sinus rhythm: a meta-analysis. Circ Heart Fail 2013;6:287292.

48. Zannad F, Anker SD, Byra WM, Cleland JGF, Fu M, Gheorghiade $M$, et al. Rivaroxaban in patients with heart failure, sinus rhythm, and coronary disease. N Engl J Med 2018;379:13321342.

49. Greenberg B, Neaton JD, Anker SD, Byra WM, Cleland JGF, Deng $H_{\text {, et }}$ al. Association of rivaroxaban with thromboembolic events in patients with heart failure, coronary disease, and sinus rhythm: a post hoc analysis of the COMMANDER HF Trial. JAMA Cardiol 2019;4:515-523.

50. Falck-Ytter $Y$, Francis CW, Johanson NA, Curley C, Dahl OE, Schulman $S$, et al. Prevention of VTE in orthopedic surgery patients: antithrombotic therapy and prevention of thrombosis, 9th ed: American College of Chest Physicians Evidence-Based Clinical Practice Guidelines. Chest 2012;141(2 Suppl):e278S-e325S.

51. RE-MOBILIZE Writing Committee, Ginsberg JS, Davidson BL, Comp PC, Francis CW, Friedman RJ, et al. Oral thrombin inhibitor dabigatran etexilate vs North American enoxaparin regimen for prevention of venous thromboembolism after 
knee arthroplasty surgery. J Arthroplasty 2009;24:1-9.

52. Eriksson BI, Dahl OE, Huo MH, Kurth AA, Hantel S, Hermans-

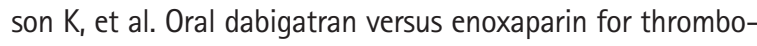
prophylaxis after primary total hip arthroplasty (RE-NOVATE II*): a randomised, double-blind, non-inferiority trial. Thromb Haemost 2011;105:721-729.

53. Friedman RJ, Dahl OE, Rosencher N, Caprini JA, Kurth AA, Francis $C W$, et al. Dabigatran versus enoxaparin for prevention of venous thromboembolism after hip or knee arthroplasty: a pooled analysis of three trials. Thromb Res 2010;126:175-182.

54. Turpie AG, Lassen MR, Davidson BL, Bauer KA, Gent M, Kwong LM, et al. Rivaroxaban versus enoxaparin for thromboprophylaxis after total knee arthroplasty (RECORD4): a randomised trial. Lancet 2009;373:1673-1680.

55. Turpie AG, Lassen MR, Eriksson BI, Gent M, Berkowitz SD, Misselwitz $F$, et al. Rivaroxaban for the prevention of venous thromboembolism after hip or knee arthroplasty: pooled analysis of four studies. Thromb Haemost 2011;105:444-453.

56. Lassen MR, Raskob GE, Gallus A, Pineo G, Chen D, Portman RJ. Apixaban or enoxaparin for thromboprophylaxis after knee replacement. N Engl J Med 2009;361:594-604.

57. Lassen MR, Raskob GE, Gallus A, Pineo G, Chen D, Hornick P, et al. Apixaban versus enoxaparin for thromboprophylaxis after knee replacement (ADVANCE-2): a randomised doubleblind trial. Lancet 2010;375:807-815.

58. Lassen MR, Gallus A, Raskob GE, Pineo G, Chen D, Ramirez LM, et al. Apixaban versus enoxaparin for thromboprophylaxis after hip replacement. N Engl J Med 2010;363:24872498.

59. Fuji T, Wang CJ, Fujita S, Kawai Y, Nakamura M, Kimura T, et al. Safety and efficacy of edoxaban, an oral factor $\mathrm{Xa}$ inhibitor, versus enoxaparin for thromboprophylaxis after total knee arthroplasty: the STARS E-3 trial. Thromb Res 2014;134:11981204.

60. Fuji T, Fujita S, Kawai Y, Nakamura M, Kimura T, Fukuzawa $M_{1}$ et al. Efficacy and safety of edoxaban versus enoxaparin for the prevention of venous thromboembolism following total hip arthroplasty: STARS J-V. Thromb J 2015;13:27.

61. Kawai Y, Fuji T, Fujita S, Kimura T, Ibusuki K, Abe K, et al. Edoxaban versus enoxaparin for the prevention of venous thromboembolism after total knee or hip arthroplasty: pooled analysis of coagulation biomarkers and primary efficacy and safety endpoints from two phase 3 trials. Thromb J 2016;14:48.

62. Schulman S, Kearon C, Kakkar AK, Mismetti P, Schellong S, Er-

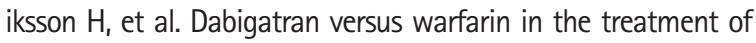
acute venous thromboembolism. N Engl J Med 2009;361:23422352.
63. Schulman S, Kakkar AK, Goldhaber SZ, Schellong S, Eriksson $\mathrm{H}$, Mismetti $\mathrm{P}$, et al. Treatment of acute venous thromboembolism with dabigatran or warfarin and pooled analysis. Circulation 2014;129:764-772.

64. Schulman S, Kearon C, Kakkar AK, Schellong S, Eriksson $H_{\text {, }}$ Baanstra $D$, et al. Extended use of dabigatran, warfarin, or placebo in venous thromboembolism. N Engl J Med 2013;368:709718.

65. EINSTEIN Investigators, Bauersachs R, Berkowitz SD, Brenner B, Buller HR, Decousus $H_{1}$ et al. Oral rivaroxaban for symptomatic venous thromboembolism. N Engl J Med 2010;363:2499-2510.

66. EINSTEIN-PE Investigators, Büller HR, Prins MH, Lensin AW, Decousus $H_{1}$ Jacobson $B F$, et al. Oral rivaroxaban for the treatment of symptomatic pulmonary embolism. N Engl J Med 2012;366: 1287-1297.

67. Agnelli G, Buller HR, Cohen A, Curto M, Gallus AS, Johnson $M$, et al. Oral apixaban for the treatment of acute venous thromboembolism. N Eng/ J Med 2013;369:799-808.

68. Agnelli G, Buller HR, Cohen A, Curto M, Gallus AS, Johnson $M$, et al. Apixaban for extended treatment of venous thromboembolism. N Engl J Med 2013;368:699-708.

69. Hokusai-VTE Investigators, Büller HR, Décousus H, Grosso MA, Mercuri M, Middeldorp $S$, et al. Edoxaban versus warfarin for the treatment of symptomatic venous thromboembolism. N Engl J Med 2013;369:1406-1415.

70. Kearon C, Akl EA, Ornelas J, Blaivas A, Jimenez D, Bounameaux $\mathrm{H}$, et al. Antithrombotic therapy for VTE disease: CHEST guideline and expert panel report. Chest 2016;149:315-352.

71. Mazzolai L, Aboyans V, Ageno W, Agnelli G, Alatri A, Bauersachs $R_{1}$ et al. Diagnosis and management of acute deep vein thrombosis: a joint consensus document from the European Society of Cardiology working groups of aorta and peripheral vascular diseases and pulmonary circulation and right ventricular function. Eur Heart J 2018;39:4208-4218.

72. Blom JW, Doggen CJ, Osanto S, Rosendaal FR. Malignancies, prothrombotic mutations, and the risk of venous thrombosis. JAMA 2005;293:715-722.

73. Raskob GE, van Es N, Verhamme P, Carrier M, Di Nisio M, Garcia $D$, et al. Edoxaban for the treatment of cancer-associated venous thromboembolism. N Engl J Med 2018;378:615624.

74. Young AM, Marshall A, Thirlwall J, Chapman O, Lokare A, Hill $C_{\text {, et }}$ al. Comparison of an oral factor $\mathrm{Xa}$ inhibitor with low molecular weight heparin in patients with cancer with venous thromboembolism: results of a randomized trial (SELECT-D). J Clin Oncol 2018;36:2017-2023.

75. McBane li R, Loprinzi CL, Ashrani A, Perez-Botero J, Leon Ferre RA, Henkin $\mathrm{S}$, et al. Apixaban and dalteparin in active 
malignancy associated venous thromboembolism: the ADAM VTE trial. Thromb Haemost 2017;117:1952-1961.

76. McBane RD, Wysokinski WE, Le-Rademacher J, Ashrani AA, Tafur AJ, Gundabolu K, et al. Apixaban, dalteparin, in active cancer associated venous thromboembolism, the ADAM VTE trial. Blood 2018;132(Suppl 1):421.

77. NCCN Clinical Practice Guidelines in Oncology (NCCN Guidelines): cancer-associated venous thromboembolic disease version 1.2018. National Comprehensive Cancer Network. www.nccn.org/professionals/physician_gls/pdf/vte.pdf. Accessed September 24, 2019.

78. Kahn SR, Lim W, Dunn AS, Cushman M, Dentali F, Akl EA, et al. Prevention of VTE in nonsurgical patients: antithrombotic therapy and prevention of thrombosis, 9th ed: American College of Chest Physicians Evidence-Based Clinical Practice Guidelines. Chest 2012;141(2 Suppl):e195S-e226S.

79. Hull RD, Schellong SM, Tapson VF, Monreal M, Samama MM, Nicol $P$, et al. Extended-duration venous thromboembolism prophylaxis in acutely ill medical patients with recently reduced mobility: a randomized trial. Ann Intern Med 2010;153:8-18.
80. Cohen AT, Spiro TE, Büller HR, Haskell L, Hu D, Hull R, et al. Rivaroxaban for thromboprophylaxis in acutely ill medical patients. N Engl J Med 2013;368:513-523.

81. Goldhaber SZ, Leizorovicz A, Kakkar AK, Haas SK, Merli G, Knabb RM, et al. Apixaban versus enoxaparin for thromboprophylaxis in medically ill patients. N Engl J Med 2011;365:21672177.

82. Cohen AT, Harrington RA, Goldhaber SZ, Hull RD, Wiens $B L$, Gold $A$, et al. Extended thromboprophylaxis with betrixaban in acutely ill medical patients. N Engl J Med 2016;375:534544.

83. Gibson CM, Chi G, Halaby R, Korjian $S$, Daaboul $Y$, Jain $P$, et al. Extended-duration betrixaban reduces the risk of stroke versus standard-dose enoxaparin among hospitalized medically ill patients: an APEX Trial Substudy (Acute Medically III Venous Thromboembolism Prevention with Extended Duration Betrixaban). Circulation 2017;135:648-655.

84. Pengo V, Denas G, Zoppellaro G, Jose SP, Hoxha A, Ruffatti A, et al. Rivaroxaban vs warfarin in high-risk patients with antiphospholipid syndrome. Blood 2018;132:1365-1371. 